تصميم كتاب إلكتروني تفاعلي قائم على برنامـج

القرائية لتنمية التحصيل القرائي في اللغة العربية

لاى تلاميذ الصف الثالث الابتدائي

محمل عطية السيد أحمد عطية

$$
\text { معلم خبير لغة عربية }
$$

مدرب أكاديمي على برنامج القرائية

أ.د / عبدالعزيز طلبة عبدالحميد عليد

أستاذ ورئيس قسم تكنولوجيا التعليم

كلية التربية- جامعة المنصورة

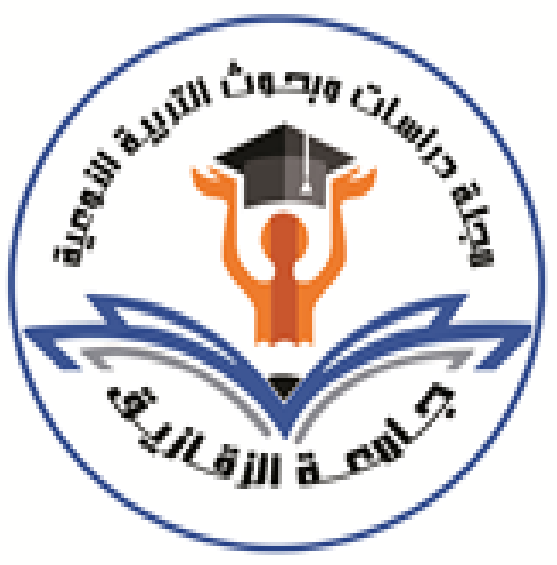

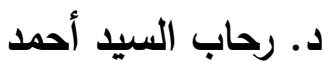

مدرس تكنولوجيا التعليم

كلية التربية النوعية- جامعة الزقازيق

المجلة العلمية المحكمة لدراسات وبحوث التربية النوعية

المجلد الثامن- العدد الأول- مسلسل العدد (15)- يناير 2022- الجزء الأول

$$
\text { رقم الإيداع بدار الكتب } 24274 \text { لسنة } 2016
$$

ISSN-Print: 2356-8690 ISSN-Online: 2356-8690

https://jsezu.journals.ekb.eg موقع المجلة عبر بنك المعرفة المصري JSROSE@foe.zu.edu.eg E-mail البريد الإلكتروني للمجلة 
تصميم كتاب إلكتروني تفاعلي قائم على برنامج القرائية لتنمية التحصيل القرائي في اللغة العربية لاى تلاميذ الصف الثالث الابتدائي

إعداد

\section{محم عطيه السيد أحمد عطيه}

معلم خبير لغــة عربيــة

مدرب أكاديمي على برنامج القرائية

$$
\text { ددرس تكنولوجيا التعليم السيد أحمد }
$$

كلية التربية النوعية- جامعة الزقازيق

\section{أ.د. عبدالعزيز طلبة عبدالحميد} أستاذ ورئيس قسم تكنولوجيا التعليم

كلية التربية- جامعة المنصورة

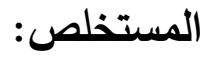

استهدف البحث الحالي التعرف على فعالية كتاب إلكتروني تفاعلي قائم على برنامج القرائية في تتمية التحصيل القرائي في اللغة العربية لدى تلاميذ الصف الثالث الابتدائي، وقد تكونت عينة البحث من (ب9) تلميذ/ تلميذة من تلاميذ الصف الثالث الابتدائي بمدرسـة المؤانسـة الرسمية لغات التابعة لإدارة كفر صقر التابعة لمديريـة التربيـة والتعليم بالثـرقية، تم اختيارهم بطريقة

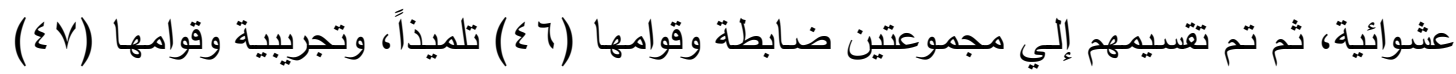
تلميذاً، وتمثلت أدوات البحث في اختبار تحصيل الجوانب المعرفية (من إعداد الباحث)، كتاب إلكتروني تفاعلي قائم على القرائية كطريقة تدريس (من إعداد الباحث)، قائمة الأهداف المعرفية للوحدة الأولى مـن كتاب اللغـة العربيـة للصف الثالث الابتدائي الفصل الدراسـي الأول للعـام

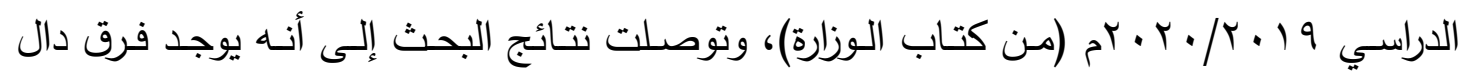
إحصائياً في مستوى التحصيل القرائي، لتلاميذ المجموعة التجريبية في التطبيقين القبلي والبعدي، لصالح التطبيق البعدي يعود لاستخدام الكتاب الإلكتروني التفاعلي القائم على برنامج القرائية، كما يوجد فرق دال إحصائياً في مستوى تحصيل تلاميذ المجموعتين التجريبية والضـابطة في لي لئي التطبيق البعدي للاختبـار التحصـيلي لصـالح المجموعـة التجريبيـة يعـود لاسـتخدام الكتـاب الإلكتروني التفاعلي القـائم على برنـامج القرائيـة، كمـا يوجد أثر للكتاب الإلكتروني التفاعلي

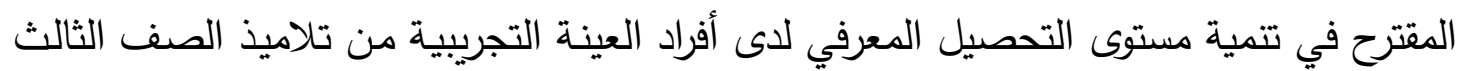


تعدت القراءة كونها حاجة إلى اعتبارها ضرورة في عصرنا هذا، وتحتل القراءة بالنسبة للإنسان أهمية كبرى فهي وسيلته للتعلم والتعليم واكتساب المعرفة بصفة عامة، كما أنها تمثل فئل بعض وسائل استمتاعه وترفيها، ومن ناحية أخرى تعتبر القراءة من أهم المهارات المكتسبة التي

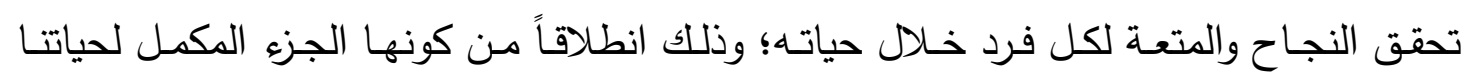
الشخصية والعملية وهي مفتاح أبواب العلوم والمعارف والمهارات الحياتية والخبرات، وقد حازت

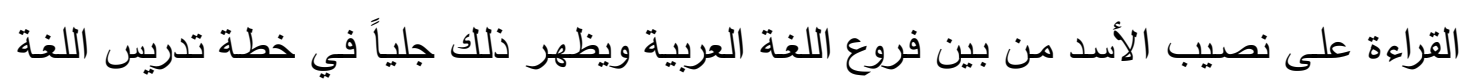
العربية في المدارس الابتدائية داخل جمهورية مصر العربية إذ تمثل هذه النسبة هب\% من بين

(1) (أفرعها. شكل في ل)

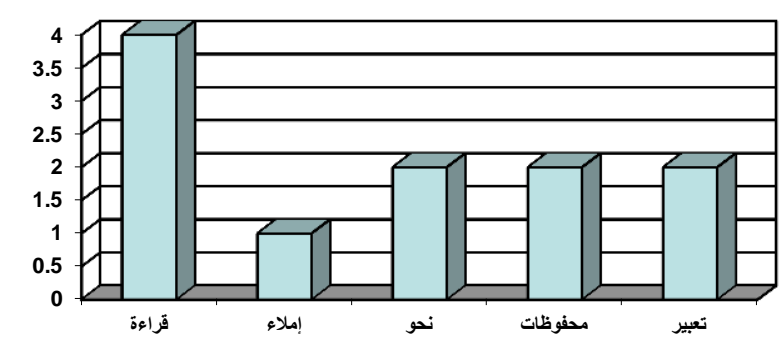

الصوف الثلاثة الثانيةه

شكل (1) نسبة تمثيل القراءة مقارنة بباقي أفرع اللغة العربية

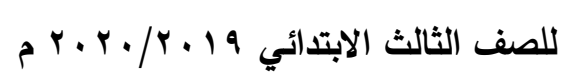

وعلى الرغم من هذا الاهتمام الرسمي بالقراءة إلا أننا نلمس من قريب أو بعيد ضعفاً مالعائ

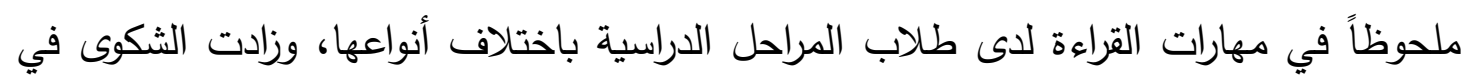
الآونة الأخيرة وتفاقت المشكلة حتى ظهر ما يعرف اصطلاحاً بالأمية في التعليم، وبتحليل

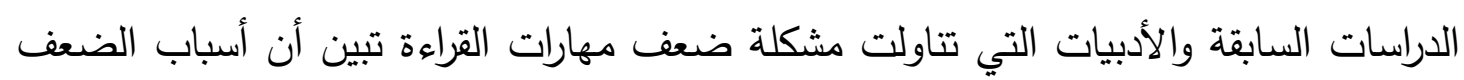
القرائي ترجع إلى: (ضعف مستوى التحليل، والتركيب، والتوليف الصوتي للكلمات والرموز، وتطابقات الوحدات الصوتية مع ما يقابلها من رموز، والتهجي وتجزئة الكلمة إلي مقاطع، وتجزئة المقطع الواحد، وربط الرموز المطبوعة بالأصوات التي تقابلها، والحروف المترابطة التي

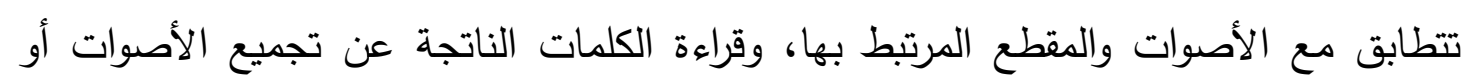

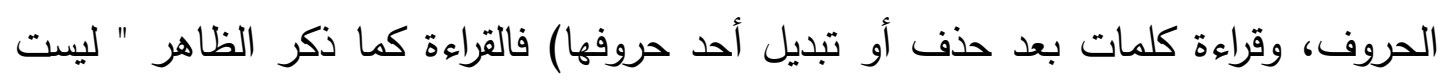


بالعملية السهلة، بل هي مهارة لغوية دقيقة وعقلية معقدة، وعملية صوتية تتأثر بجملة من

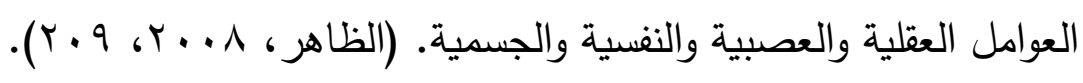
وقد تعود هذه المشكلة لأسباب أخرى منها ما ذكره أبو الهيجاء بقوله " قد ينجح المعلمون في تعليم تلاميذهم القراءة والكتابة، وقد يفشلون لأسباب كثيرة، ومعظد أسباب الفشل في السنوات الأولى تعود إلى المعلمين أنفهه، وأساليبهم التربوية، أو طرق تدريهه، أو طرق

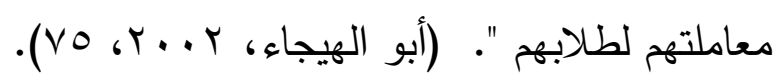
وينبغي أن يهدف منهج اللغة العربية في الحلقة الأولى من التعليم الأساسي، والصفوف الثلاثة الأولى منها خاصة إلى: تتمية المهارات الأساسية اللزمة عند التلميذ للقراءة، وجذب الميل لديه نحو القراءة ولا يكون ذلك إلا بإثراء المحتوى بالوسائط التكنولوجية الحديثة، وتحسين طرق وأساليب التدري؛ لينمو الاستعداد لدى التلاميذ في إقبالهم على حب القراءة وتعلهها، فقد أوضحت دراسة سيامبا أن دافعية المبتدئين في القراءة نحو القراءة واختياراتهم للنصوص المقروءة له بالغ الأثر على تحصيلهم في مادتي القراءة والكتابة، إلى جانب رغبتهم بالمشاركة في الأنشطة المتعلقة بالقراءة في السنوات الأولى من دراستهم، وخلصت نتائج الدراسة إلى مجموعة من الإمكانات والوعود التي تقدمها الكتب الإكترونية لتعزيز دافعية القراء المبتدئين نحو القراءة. سيامبا، (Ciampa, 2012).

وقد نادت مجموعة من الدراسات بتوظيف الكتب الإلكترونية في العملية التعليمية، كدراسة عبدالكريخ (11 • r) التي أكدت على ضرورة الاستفادة من الكتب الإكترونية المتاحة على شبكة الانترنت؛ نظراً لما تضمنه من مزايا تربوية متعددة، ودراسة عزمي والمرداني ( • ( ا ( التي أوصت بضرورة الاهتمام بتصميم كتب إلكترونية في ضوء المعايير التربوية الهادفة، وفي نفس السياق أوصت دراسة الزق (^ . . ب) بتخصيص مقررات كاملة أو أجزاء من تلك المقررات في شكل كتب إلكترونية ليدرسها الطلاب. ويرى استرادا وكوناوي (Estrada \& Conaway, 2012) بأن الكتب الإكترونية تمثل الخطوة التالية في مجال الابتكارات التعليمية، لا سيما وأن الطلاب يفضلون الكتب الإلكترونية على المطبوعة، ويجدونها أكثر مواعمة للعصر الرقمي الجديد الذي يتعلمون فيه، وهذا يتجلى مع ظهور الجيل الجديد من الكتب الإلكترونية والمتمثل في الكتب الإكترونية التفاعلية (Interactive e.Book) التي تتيح لمستخدميها الكثير من الأدوات التفاعلية إلى 
جانب إتاحتها لشبكات التواصل الاجتماعي التي تسهل التواصل وتبادل الملاحظات والتعليقات Binas, Stancel, Novak, \& . والمشاركات الفاعلة بين القراء والمؤلفين والمتخصصين

.(Michalko, 2012)

وقد أكدت دراسة بير وواجنز (Beer \& Wagner,2011) على أهمية الكتب

الإلكترونية التفاعلية، ووصفتها بالكتب الذكية التي توفر الدعم الكامل لمستخدميها، وهذا ما يدعو إلى الأخذ بالتوجهات التربوية والتكنولوجية الحديثة في تصميم وإنتاج الكتب الإلكترونية التفاعلية التي تعمل على إثراء المحتوى التعليمي، وذللك لكونها تعتمد في طريقة تصميمها وعملها على الوسائط الفائقة، فدراسة عبدالرازق والمدين أثتبت أن الطلاب يفضلون الكتب Abdelrazek \& ) الإكترونية التفاعلية، وما تتيحه من مزايا متعددة أثناء تعليمهر. .(Elmodyan, 2013

كما أظهرت العديد من الدراسات مثل دراسة فراي (Frye,2014)، وسامريجرونجرج Samrejrongroj, Boonsiri, Thunyaharn, \& Sangarun ) وبنسري وثنيهرن وسنجارن

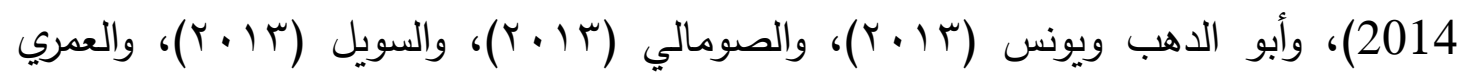
(Y)

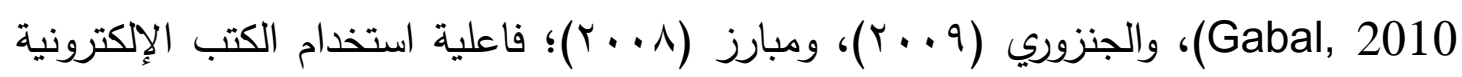
بنمطها التفاعلي في تتمية العديد من المهارات العلمية والعملية لدختلف المراحل الدراسية. من هذا المنطلق، ولكون اللغة منظومة مترابطة تؤثر وتتأثر بالمجتمع المحيط، ونظرًا لكونها فاعلة في تعليم وتعلم المواد الدراسية، فهي أداة المتعلم في التنكير والتعلم والتواصل مع بحن

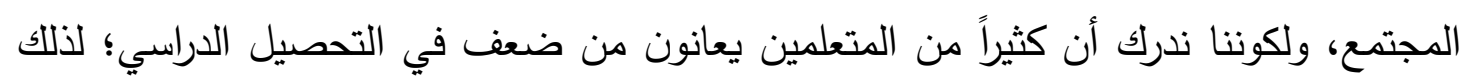
سيتم تتاول فكرة تنمية التحصيل الدراسي في اللغة العربية، ومعالجتها لدى تلاميذ الصف الثالث الابتدائي، بقياس مدى فاعلية كتاب إلكتروني تفاعلي مقترح قائم على برنامج القرائية؛ نظراً لما شهدته الأوساط التعليمية من: - تقدم مذهل في مجال الكتب الإلكترونية التفاعلية. - نجاح برنامج القرائية في تتاوله للطريقة الصوتية لتتمية مهارات القراءة والكتابة. 
نبع الإحساس بمشكلة البحث الحالي من عدة مصادر ، منها: أولاً. الخبرة العملية للباحث:

من خلال عمل الباحث بتدريس مادة اللغة العربية لتلاميذ المرحلة الابتدائية لاحظ أن التلاميذ لا يمتلكون مهارات القراءة بالقدر الكافي الذي يمكنهم من التعلم بشكل جيد، فالقراءة أحد أهم أدوات التعلم التي يجب أن يتسلح بها التلميذ حتى يستطيع أن يمارس نشاطه التحصيلي بسلاسة ليس في اللغة العربية وحسب وإنما في بقية المواد الدراسية المقررة عليه. ومن خلال خبرة الباحث في مجال التدريب الأكاديمي لمعلمي اللغة العربية في مرحلة التعليم الأساسي، على برنامج تتمية مهارات القراءة والمعروف اصطلاحاً باسم (القرائية) كطريقة تدري، لاحظ الباحث ثقل مهام الإعداد والتطبيق للأنثطة والاستراتيجيات على كاهل المعلم ويرجع ذلك لتعددها ونموها المتسارع، فضلاً عن مهام التطبيق، والتقويم، ورصد الإتقان عقب لإعب كل وحدة دراسية، مما قلل من فرص التكرار وتدريب التلاميذ بشكل كافي في ظل الكثافة المرتفعة أثناء الدروس. ثانياً: نتيجة التقييم القومي الثاني بدراسة وتحليل نتائج التقييم القومي الثاني الذي طبق ضمن برنامج القرائية، على تلاميذ الصف الثالث الابتدائي بجمهورية مصر العربية خلال العامين الدراسيين سا • بام، ع ا • ام على التوالي، لاحظ الباحث وجود تحسن إلى حد ما ضعيف، في نتائج أداء التلاميذ لتقييم ؟ ا • آم، فهي لم ترقى لمستوى الإجادة إلا في مهامة واحدة من أصل ستة، وهي المتعلقة بمهارة التعرف على أصوات الحروف (عدد الأصوات الصحيحة في الدقيقة الواحدة) حيث بلغت نتيجتها VTV\% بزيادة قدرها • (1\% عن مثيلتها في عام با . Yم، مع ملاحظة تدني في مهارات القراءة مثل: مهارة فهم المسموع التي سجلت ع٪\% بنسبة تراجع ^٪\%، ومهارة الطلاقة في القراءة الشفهية حيث سجلت OV\% بنسبة تراجع r\%، ومهارة فهم المقروء حيث بلغت • ؛ \% بنسبة زيادة ^^\%، كما هو موضح بالجدول رقم (1). 
جدول رقم ( ) ملخص درجات تقييم مهارات القراءة بالنسبة لعدد البنود

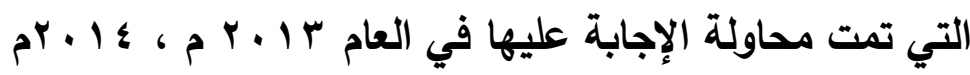

\begin{tabular}{|c|c|c|}
\hline \multicolumn{2}{|c|}{ النسبة المئوية للبنود الصحيحة } & \multirow{2}{*}{ المهمة الفرعية } \\
\hline$r+1 \varepsilon$ & $r+1 T$ & \\
\hline$\%$ \% & $\% \circ v$ & (عدد الحروف الصحيحة في الدقيقة) \\
\hline$\% \varepsilon \varepsilon$ & $\%$ ro & (عدد الكلمات الصحيحة في الدقيقة) \\
\hline$\% \circ v$ & $\% ० 9$ & 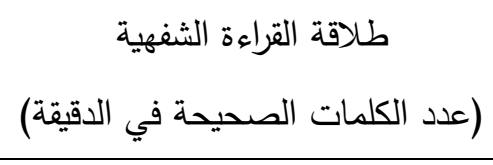 \\
\hline$\% \varepsilon$ & \%rr & الفهم القرائي (؟ بحد أقصى) \\
\hline$\%$ \% & $\% \leq 7$ & فهم المسموع (V بحد أقصى) \\
\hline$\%$ \% & $\%$ \% & متاهة الفهم (ء ( بحد أقصى) \\
\hline
\end{tabular}

من هنا تعمق الإحساس بحاجة التلميذ لتكرار وممارسة المهارات أكثر من مرة حتى يتقنها، مع الحاجة للتدريب المستمر عليها؛ حتى يصل لمستوى أفضل في التحصيل القرائي من خلال وسيلة تكنولوجية تتسم بالإتاحة وجذب الميل لديه لا تكل ولا تمل من التكرار، فالتلاميذ في حاجة للاعم بشكل فردي مباشر لتحقيق التعلم المنشود، والمعلم هو الآخر في حاجة لوسيلة تكنولوجية تساعده بشكل أو بآخر في تتمية مهارات القراءة لاى التلاميذ وسط خضم المسئوليات التي أتقلت عاتقيه، وبالتالي تتحقق أهداف القرائية كطريقة تدريس تستهدف تتمية مهارات القراءة وبالتالي التحصيل القرائي لاى تلاميذ الصفوف الثلاثة الأولى من مرحلة التعليم الأساسي والوقاية من السقوط في مستنقع العجز القرائي والأمية في التعليم، والتي تم تعميمها على جميع

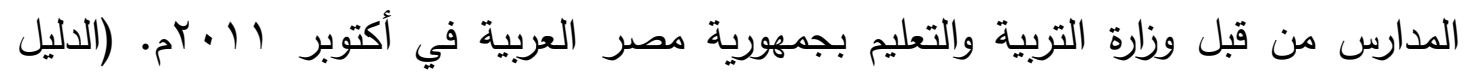
الإرشادي لتتمية مهارات القراءة للصف الأول الابتدائي، (1 ـ ب). ثالثاً. نتائج الاراسات السابقة: أثبت عديد من الدراسات السابقة فاعلية الكتاب الإلكتروني التفاعلي في تتمية المهارات، وكذللك التحصيل المعرفي ومنها: 
توصلت العديد من الدراسات إلى فاعلية الكتاب الإلكتروني في تتمية المهارات منها

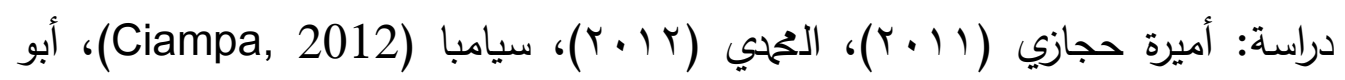

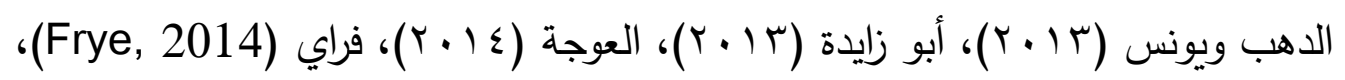

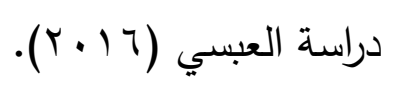

- - دراسات اهتمت بالتحصيل المعرفي:

أثتتت دراسات فاعلية الكتاب الإلكتروني التفاعلي في تتمية التحصيل المعرفي منها

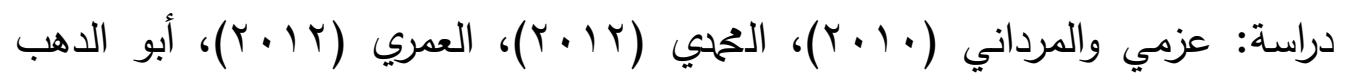

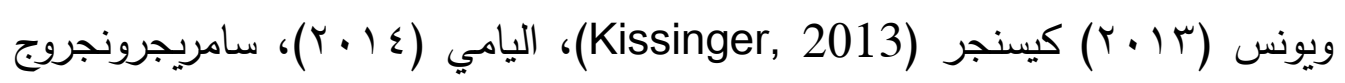

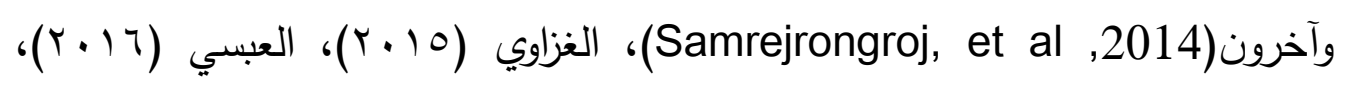
هوانج، ولاي (Hwang, et Lai, 2017).

\section{- دراسات اهتمت بالقراءة:}

بعد الاطلاع على الدراسات والأدبيات التي تناولت التحصيل القرائي والفهم والطلاقة

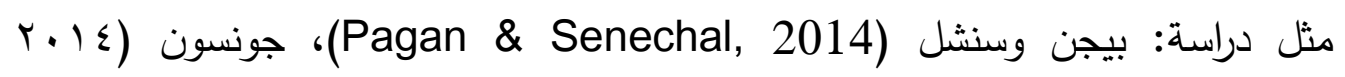
Johnson،

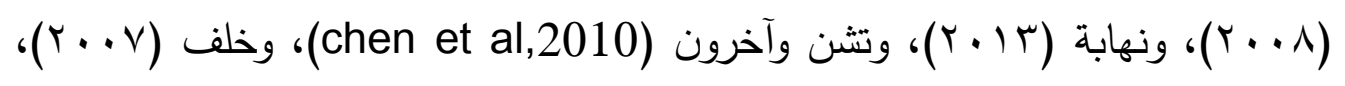

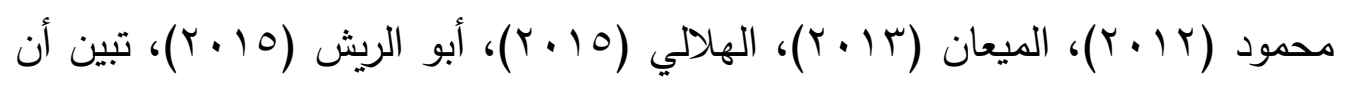

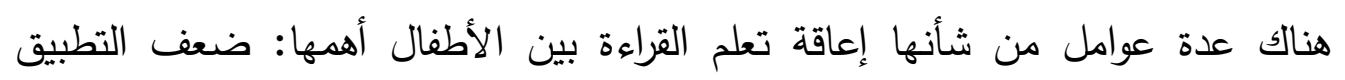
الدقيق والسلس لمهارات قراءة النصوص، وعدم القدرة على اكتساب استراتيجيات الفهم القرائي وتطبيقها في قراءة النصوص لزيادة التحصيل. رابعاً. الاراسة الاستكثافية: قام الباحث بدراسة استطلاعية استهدفت الكثف عن مدى وجود مظاهر للضعف القرائي للى تلاميذ المرحلة الابتدائية تستوجب الالتفات إليها ومعالجتها، وتمت الدراسة الاستطلاعية من

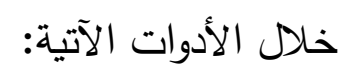


1. تطبيق استبيان على عينة ممثلة لمعلمي اللغة العربية في المرحلة الابتدائية بإدارة كفر

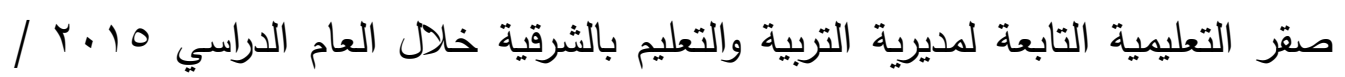

$$
\text { . } r \cdot 17
$$

r. إجراء مقابلات مع القائمين على تدريس اللغة العربية. r. الاطلاع على البرمجيات المستخدمة في تدريس مهارات القراءة للصف الثالث الابتدائي في المدارس التابعة لإدارة كفر صقر التعليمية بمحافظة الشرقية. أسفرت نتائج الدراسة الاستطلاعية عن الآتي:

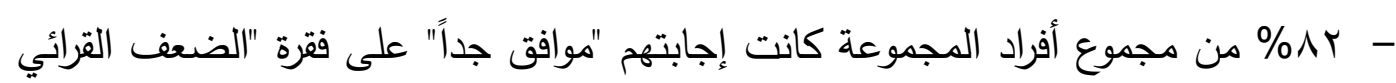

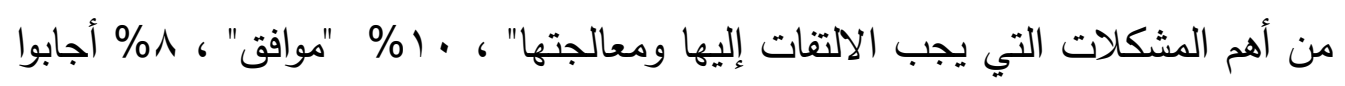
" لا أعلم" كما يوضحه المخطط البياني التالي شكل رقم (r)

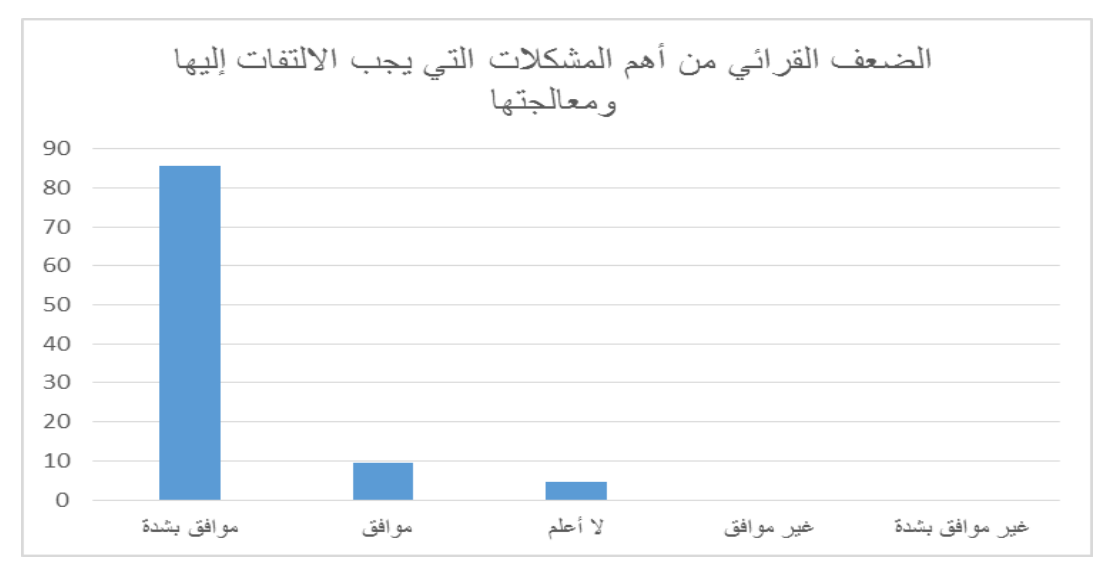

شكل رقم (r) نسبة الإجابة على فقرة " الضعف القرائي من أهم

المشكلات التي يجب الالتفات إليها ومعالجتها" الاجها

- ظهرت الحاجة لدراسة مهارات القراءة باستخدام التقنيات الحديثة؛ لتتمية التحصيل القرائي.

- عدم وجود برمجيات تفاعلية تتناول برنامج القرائية.

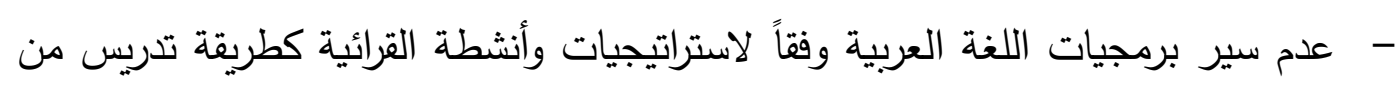

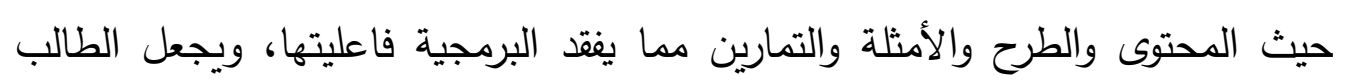
بمنأى عن تطور طرق تدريس اللغة العربية. 
بناء على ما سبق نجد أن الدراسة الاستكثافية قد أوضحت ضعفاً في مهارات القراءة وبالتحديد مهارات: (فهر المقروء والمسموع، والطلاقة في القراءة الشفهية)، وما ترتب عليه من ضعف في التحصيل القرائي لدى تلاميذ الصف الثالث الابتدائي، ونظراً للتجريد الذي تتسم به أجزاء مقرر القراءة فإنه من المناسب استخدام وسائل تدريس تقوم بتجسيد هذه العلاقات المجردة وبيان العلاقات باستخدام الصور المتحركة والفيديو والفلاشات والصوت وغيرها من الوسائط التي تحقق جذب الميل ومتعة التعلم، مما يحتم علينا تصميم وتطوير وسيلة تكنولوجية تفاعلية جذابة تثير دافعية التلميذ وتدعم التكرار والتعزيز والتغذية المرتدة الناجعة، والتي تتمثل في: كتاب إلكتروني تفاعلي قائم على برنامج القرائية لتتمية التحصيل القرائي من خلال تتاول الأنشطة الخاصة بفهم المقروء والمسموع، والطلاقة في القراءة الثفهية لدى تلاميذ الصف الثالث الابتدائي بإدارة كفر صقر بمحافظة الشرقية. مشكلة البحث:

مما سبق حددت مشكلة البحث في وجود ضعف في مستوى التحصيل القرائي لدى تلاميذ الصف الثالث الابتدائي، ويمكن معالجة مشكلة البحث من خلال الإجابة على السؤال الرئيس الآتي: " ما أثر كتاب إلكتروني تفاعلي قائم على برنامج القرائية في تنمية التحصيل القرائي في

مادة اللغة العربية لدى تلاميذ الصف الثالث الابتدائي؟". ويتفرع من هذا السؤال الأسئلة الفرعية الآتية:

- ما معايير تصميم كتاب إلكتروني تفاعلي قائم على برنامج القرائية لتنمية التحصيل

$$
\text { القرائي لاى تلاميذ الصف الثالث الابتدائي؟ }
$$

- ما أثر كتاب إلكتروني تفاعلي قائم على برنامج القرائية في تنمية مستوى التحصيل

$$
\text { القرائي لاى تلاميذ الصف الثالث الابتدائي؟ }
$$

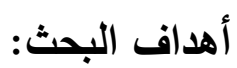

سوف يسعى هذا البحث إلى تحقيق الأهداف التالية: ا ـ الوقوف على فعالية كتاب إلكتروني تفاعلي قائم على برنامج القرائية في تتمية التحصيل القرائي لدى تلاميذ الصف الثالث الابتدائي. 
r. تصميم وتطوير كتاب إلكتروني تفاعلي قائم على برنامج القرائية لتنمية التحصيل القرائي

$$
\text { في اللغة العربية لاى تلاميذ الصف الثالث الابتدائي. }
$$

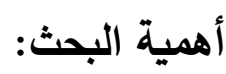

$$
\text { من المتوقع أن يفيد البحث الحالي كلاً من: }
$$

1. المعلم وذللك من خلال إعداده بما يتقق مع مطالب استخدام التقنيات الحديثة في تعليم

اللغة داخل المؤسسات التربوية القائمة على إعداد معلم اللغة العربية. r. القائمين على تطوير مناهج اللغة العربية، وذلك من خلال تخطيط مناهج تعليم اللغة العربية بما يتفق مع مطالب استخدام التقنيات الحديثة.

r. القائمين على إدارة القرائية، وذلك من خلال تعميم الاستفادة من نتائج التجربة. ع. معلمي ومشرفي اللغة العربية، وذلك من خلال معرفة الطرق والأساليب التي تسهم في تتمية التحصيل المعرفي في اللغة العربية.

0. تلاميذ الصف الثالث الابتدائي، وذللك من خلال امتلاك أهم أدوات التعلم وهي القراءة.

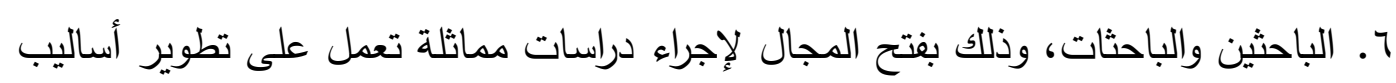
تعليم اللغة العربية في كافة مراحل التعليم. V. المصممين من حيث: إثراء مجال تصميم وإنتاج الكتب الإلكترونية التفاعلية في التعليم الابتدائي، كخطوة نحو تطوير التعلم الإلكتروني ضمن المؤسسات التعليمية كأحد توجهات وزارة التربية والتعليم بجمهورية مصر العربية.

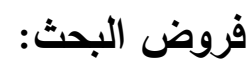

سعى البحث إلى التحقق من صحة الفروض التالية: - توجد فرق دال إحصائياً بين متوسطي درجات تلاميذ المجموعة التجريبية في التطبيقين القبلي والبعدي للاختبار التحصيلي لصالح التطبيق البعدي. - توجد فرق دال إحصائياً بين متوسطي درجات تلاميذ المجموعة التجريبية، ودرجات تلاميذي المجموعة الضابطة في التطبيق البعدي للاختبار التحصيلي لصالح تلاميذ المجموعة التجريبية. - يوجد أثر للكتاب الإكتروني التفاعلي المقترح في تنمية مستوى التحصيل القرائي لاى أفراد العينة التجريبية من تلاميذ الصف الثالث الابتدائي. 
كتاب إلكتروني تفاعلي (Interactive E Book):

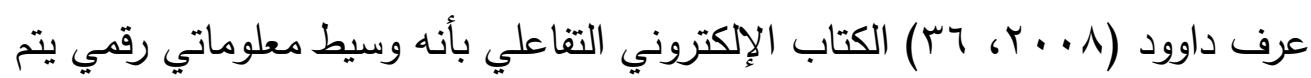
إنتاجه عن طريق إدماج المحتوى النصي للكتاب من جانب، وتطبيقات البيئة الرقمية الحاسوبية من جانب آخر ؛ وذلك لإنتاج الكتاب في شكل إلكتروني يكسبه المزيد من الإمكانيات والخيارات التي تتفوق بها البيئة الإلكترونية الافتراضية على البيئة الورقية للكتاب. التعريف الإجرائي للكتاب الإلكتروني التفاعلي (المقترح): هو مصدر تعليم وتعلم إلكتروني تفاعلي قائم على برنامج القرائية يتناول مهارات القراءة (فهم المقروء، وفهم المسموع، والطلاقة في القراءة الجهرية) في وحدة كاملة من وحدات الكتاب

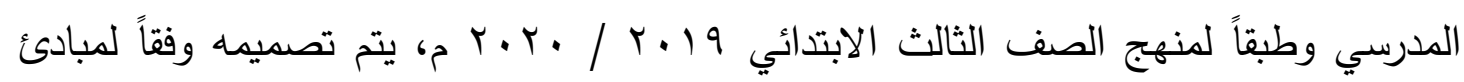
التصميم التعليمي، ويمثل بيئة تعليمية متكاملة تشمل العديد من الإمكانات الإضافية، كالوسائط المتعددة والفائقة، والاختبارات والأنشطة وأدوات التحكم والفلاشات التفاعلية والمعاجم والصوت، مما يثري المحتوى ويجعله أكثر عمقاً واتساعاً وإمتاعاً للمتعلم أثناء تعلمه. برنامج القرائية:

خطة تحسين القراءة والكتابة في الصفوف الأولى في اللغة العربية وتضم مجموعة من الاستراتيجيات والأنشطة التي تهدف إلى تتمية مهارات القراءة في الصفوف الدراسية الأولى، والتي قامت بها وزارة التربية والتعليم بجمهورية مصر العربية بالتعاون مع مشروع تحسين الأداء

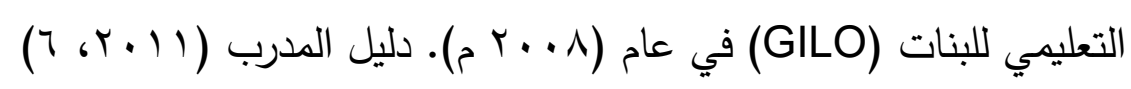
التحصيل القرائي:

يعرفه الباحث بأنه: مستوى التحصيل المعرفي الذي يصل إليه المتعلم من خلال قراءته لموضوعات القراءة التي حددها البحث في التعليم المدرسي ويقاس بالدرجة التي يحصل عليها في الاختبار التحصيلي المعد من قبل الباحث. الإطار النظري: - (إئ المحور الأول : الكتاب الإكتروني: أولاً: نشأة الكتاب الإلكتروني وتطوره: 


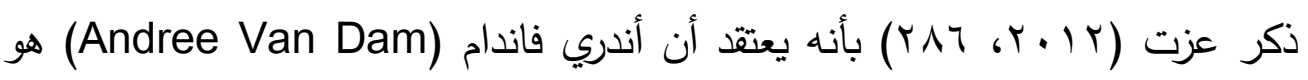
أول من صاغ مصطلح (كتاب إلكتروني) منذ العام 97 (م، عندما قاد الفريق الذي قام بإنشاء أول نظام للنصوص المتشعبة (Hypertext System) وهو النظام الذي يعمل مع الحاسبات الكبيرة. وفي السبعينات استُخدم نظام آخر هو (نظام استرجاع وتحرير الملفات) من جانب الطلاب وأعضاء الهيئة التدريسية في جامعة (براون)، ويتسم هذا النظام بديناميكية التسلسل فيما يشبه تماماً أجزاء الفصول في الكتاب.

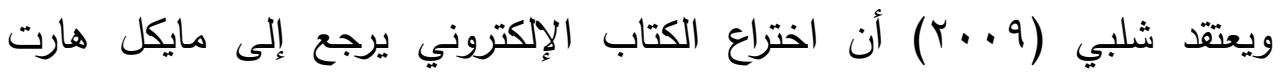
(Gutenberg وذلك في العام او (9ichael Hart) تلحويل كتب التراث إلى الثكل الإكتروني. في حين ذكرت الكميشي أن الجذور الأولى للكتاب المحوسب (الإكتروني) تعود إلى الثمانينات من القرن الماضي بالتزامن مع انتثار الحواسيب وقدرتها الفائقة على تخزين النصوص العملاقة التي تتيح للجهاز الواحد احتواء آلاف العناوين مع إمكانية نقلها على أسطوانات مدمجة لتصل إلى آلاف وربما ملايين القراء في مختلف أرجاء العالم عبر شبكة المعلومات الدولية (الإنترنت) في أقل وقت ممكن، حيث بدأ الكتاب الإلكتروني يشق طريقه بعد ذللك نحو الانتشار والمنافسة بقوة كوسيط لنقل وتسجيل المعارف البشرية.

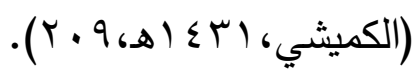
ثانياً :تعريف الكتاب الإكتروني:

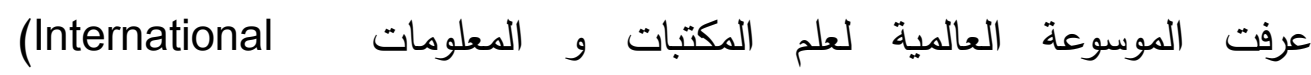
encyclopedia of information and library science) "مصطلح يستخدم للدلالة على نص أثبه ما يكون بالكتاب التقليدي غير أنه عبارة عن فورمات رقمي يتم عرضه وقراءته باستخدام الثاشات الكمبيوترية. حيث عملية نشر الكتاب فى الفورمات

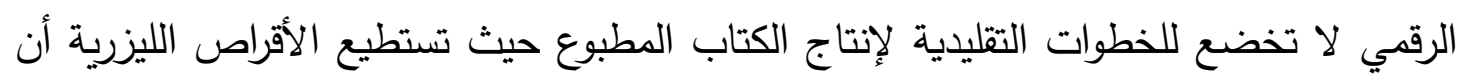
تحمل كم هائل من الكتب فى شكلها النصي فضلا عن الصور والرسوم المتحركة و الصوت"

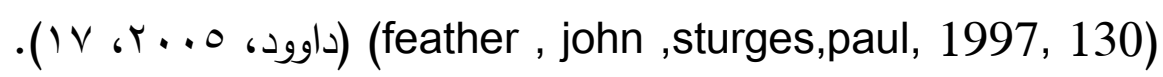

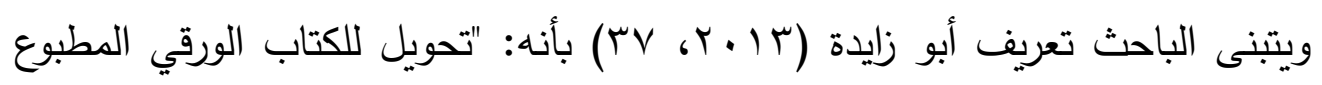
من صورته التقليدية إلى الصورة الإلكترونية، بحيث تتمتع صفحاته بوجود إمكانية التفاعل مع المجلد الثامن- العدد الأول- مسلسل العدد (15)- يناير 2022- الجزء الأول 
المادة التعليمية من خلال التحكم في محتويات الكتاب من نصوص وصور وأصوات ومقاطع فيديو بما يتناسب مع يتاسب مع قدرات المتعلم وإمكانياته" ويعرفه إجرائياً بأنه: هو مصدر تعليم وتعلم إلكتروني تفاعلي قائم على برنامج القرائية يتتاول مهارات القراءة في وحدة كاملة من وحدات الكتاب الددرسي وطبقاً لمنهج الصف الثالث

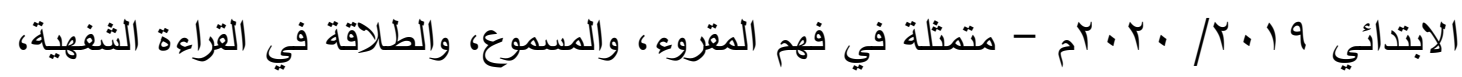
يتم تصميمه وفقاً لمبادئ التصميم التعليمي بصورة رقمية تفاعلية تتيح للطالب التحكم في النصوص والصور ومقاطع الصوت والفيديو والفلاشات والاختبارات التفاعلية مما يثري الدحتوى

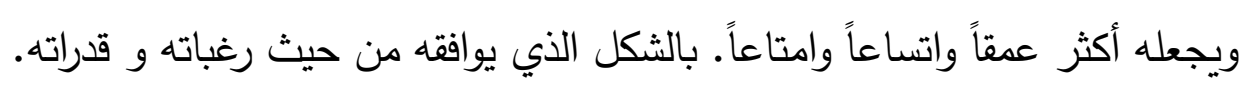
ثالثاً: تصنيفات الكتاب الإكتروني:

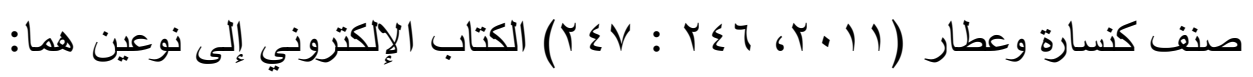

\section{1. - كتب إلكترونية غير تفاعلية:}

وهي الكتب الإككترونية التي تحمل النص أو المحتوى الرقمي في شكل ملف ( , HTML (PDF , Microsoft Word بإمكانية استعراضها بشكل مباشر أو من خلال برامج خاصة، وتشمل مجموعة من الأدوات

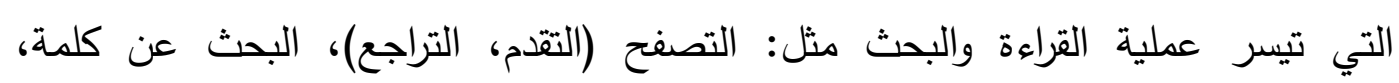
القاموس، تكبير/ تصغير الخط، إضافة التعليقات في الحواشي، تظليل الكلمات والسطور وتخطيطها، بالإضافة إلى إمكانية وضع إثارة عند مواضع معينة، وتحديد النقطة التي توقف عندها القارئ.

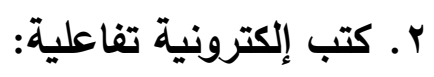

وهي كتب إلكترونية أحدث وأكثر تطوراً من سابقتها حيث تتجاوز كل ما سبق في الكتب غير التفاعلية إضافة إلى قدرتها على تحويل النص إلى صوت بشكل تفاعلي، الربط بمقاطع فيديو أو تجارب إفتراضية أو مواقع إلكترونية على الثبكة المعلومات، مع قدرتها على تقديم التغذية المرتدة على التدريبات التفاعلية والاختبارات الذاتية، بالإضافة إلى إمكانية التصفح بأكثر من نمط.

المجلد الثامن- العدد الأول- مسلسل العدد (15)- يناير 2022- الجزء الأول 


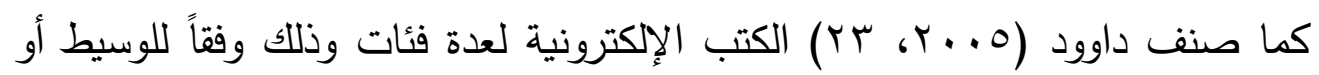
طريقة الإتاحة وأيضاً وفقاً للشكل أو طبيعة المحتوى الرقمي كما يلي: الأولى: تصنيف الكتاب الإلكتروني وفقاً للوسبط: وهي الكتب الإكترونية المسجلة على أقراص الليزر (CD , DVD - ROMs)، والكتب الإلكترونية المسجلة على أقراص مرنة (DISKS)، وتلك المنشورة على شبكة المعلومات (Online - wan , lan) الثانية: تصنيف الكتاب الإلكتروني وفقاً لطريقة الإتاحة: وهي الكتب الإلكترونية المطبوعة تحت الطلب ( Print on Demand Books ) الثالثة: تصنيف الكتب الإكترونية من حيث الثكل وطبيعة المحتوى: كتب إلكترونية نصية (Text)، كتب إلكترونية تشتمل على وسائط متعددة (Multimedia) .(Audio E- Book)

ويتقق الباحث مع تصنيف كنسارة وعطار (11 (r) الذي تتاول الكتب الإلكترونية بكلا نوعيها التفاعلي، وغير التفاعلي والتي تتضمن مكونات مشتركة كالنصوص والرسومات والصور ، إلا أن الكتاب الإكتروني التفاعلي يقدم حلولاً تعليمية متكاملة؛ نظراً لما يمتاز به من إمكانات تجعله أكثر تفضيلاً لدى الطلاب، وهذا ما أكدته العديد من الدراسات مثل دراسة: فراي (Frye,2014)، وسامرينجر وآخرون (Samrejrongroj, et al, 2014)، واليامي $\cdot(r \cdot 1 \leq)$ رابعاً: مميزات الكتاب الإكتروني التفاعلي:

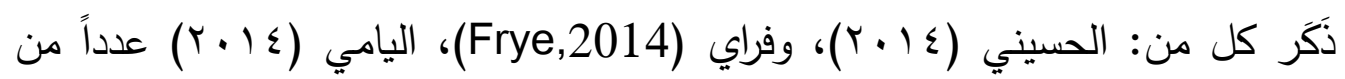
المميزات للكتاب التفاعلي المحوسب منها: - يقدم الكتاب التفاعلي المحوسب المعلومات بطريقة تشبه الواقع المحسوس الذي يعيشه المتعلم حيث يتم تحويل المعلومات من الشكل المجرد النظري إلى الشكل الحي الواقعي. - سهولة الوصول إلى محتوياته، ونقله وتحميله بين الأجهزة المتنوعة، وربطه بالمراجع العلمية. 
- يمكن أن يحتوي على وسائط متعددة (Multimedia) مثل الصور ومقاطع الفيديو والرسوم المتحركة والمؤثرات الصوتية المتتوعة وغيرها، بشكل يناسب ذوي الهمم والأصحاء.

- استخدام الأقلام الإلكترونية وإمكانية عرضه على الطلاب باستخدام أجهزة عرض

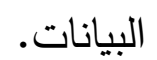

- - الإتاحة وسهولة وسرعة النشر مع إمكانية التواصل مع المؤلف وسهولة التعديل والتحديث عليه. خامساً: عوائق الكتاب الإكتروني: والئ على الجانب الآخر نجد أن الكتب الإلكترونية تواجه عدة عوائق قد تؤثر على

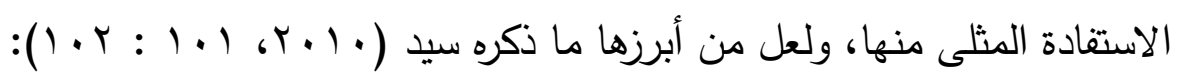
- - النفقات: والتي تتجسد في اقتناء وصيانة الأجهزة الخاصة بقراءة الكتب الإكترونية. - - التطور التكنولوجي المتسارع: فالتطور التكنولوجي المستمر فيما يخص الأجهزة والبرامج يتطلب من المستفيدين اقتناء الجديد منها والتدريب عليه لمواكبة التطور والاستفادة مما تقدمه من مزايا. - - درجة وضوح القراءة من الشاشة: إن درجة وضوح شاشات القارئات والحاسبات المحمولة. والهواتف ليست جيدة بالقدر الذي يسمح بالقراءة المستمرة من خلالها وخاصة النصوص الطويلة. -

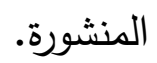
الداسات السابقة التى تناولت الكتاب الإكتروني: دراسة العوجة (ع ( ب)، استهدفت الكثف عن أثر تدريس الكسور العشرية باستخدام الكتاب الإكتروني التفاعلي وتطبيق برنامج إدارة الغرفة الصفية في اكتساب مهارات الحس بله

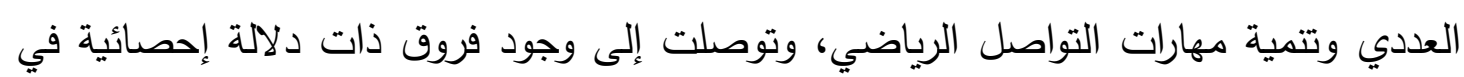

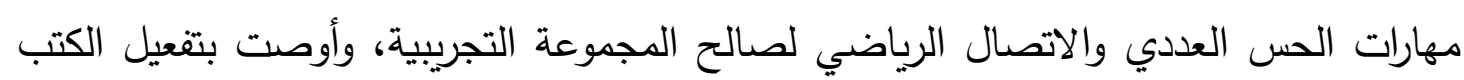
التفاعلية الإلكترونية في التدريس. 
دراسة اليامي (ع ( ب)، هدفت إلى قياس فاعلية كتاب إلكتروني تفاعلي لتتمية مهارات تصميم وتوظيف الرحلات المعرفية عبر الويب، وخلصت إلى وجود فروق ذات دلاله

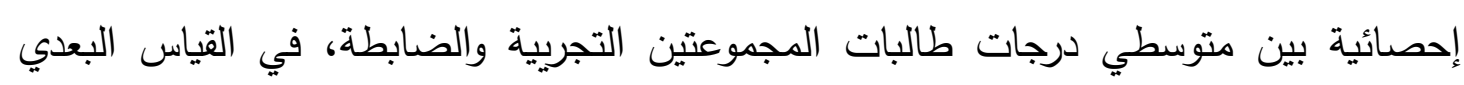
لاختبار التحصيل المعرفي لمهارات تصميم وتوظيف الرحلات المعرفية عبر الويب لصالح المجموعة التجريبة.

دراسة فراي (Frye, 2014)، استهدفت تلك الدراسة التعرف على انعكاسات الكتب

الإلكترونية التفاعلية فى الفهم ،حيث بحثت الدراسة حول كيفية تأثير المزايا التفاعلية للكتب الالكترونية على الفهم والسلوكيات أثناء القراءة، وتوصلت النتائج إلى أنه يوجد تحسن فى مستوى تائر فهم الطلاب مع مرور الوقت.

دراسة سامريجرونجروج وآخرون (Samrejrongroj, et al, 2014)، استهدفت التعرف على مدى فاعلية كتاب إلكترونى مقترح على المعارف المكتسبة فى مجال الطب وتشخيص الأمراض، ورضا الطلاب عنه، وتوصلت إلى فرق دال إحصائياً بين متوسطي درجات

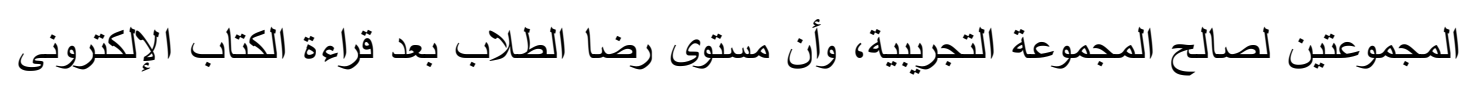
جيداً ويتسم بالإيجابية.

دراسة الغزاوي (10 • ب)، استهدفت بيان أثر أنماط التفاعل بين النص والصورة داخل

الكتاب الإكتروني في التحصيل الفوري وكذلك في التحصيل المرجأ لتلاميذ المرحلة الابتدائية وقياس مدى اتجاهاتهم نحو استخدام الكتب الإكترونية، وتوصلت إلى أن الكتاب الإلكتروني وفر

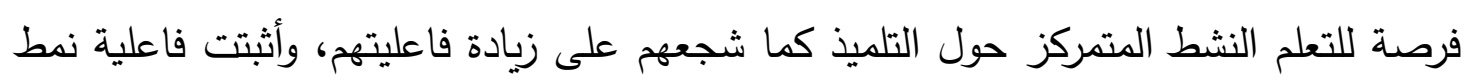
تفاعل (النص والصورة معاً) في زيادة التحصيل المعرفي وتتميه اتجاهات تلاميذ المرحلة الابتدائية نحو استخدام الكتب الإكترونية.

دراسة العبسي (T ( 1 Y)، استهدفت استقصاء أثر توظيف كتاب تفاعلي في تتمية

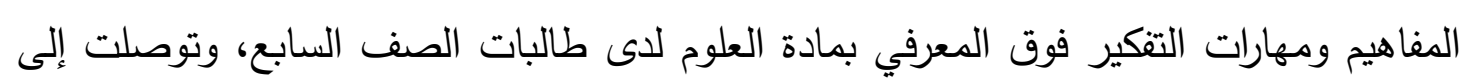
وجود فرق دال إحصائياً بين متوسطي درجات المجموعتين لصالح المجموعة التجريبية في وني اختبار المفاهيم وكذلك اختبار مهارات التفكير فوق المعرفي. 
دراسة هوانج، ولاي (Hwang, et Lai, 2017)، استهدفت قياس أثر كتاب إلكتروني تفاعلي قائم على التعلم المعكوس في مد جسور التواصل وتسهيل تعلم الرياضيات من خلال توفير الدعم لمحتويات التعلم التفاعلي المقدمة على الأجهزة النقالة، وأظهرت النتائج التجريبية أن النهج المقترح لا يعزز فقط الطلاب الكفاءة الذاتية لتعلم الرياضيات ولكن أيضا لإسهات تحسين التحصيل الدراسي.

وبالنظر إلى الاراسات السابقة نجد أنه:

- - جميع الدراسات السابقة ترتبط بالبحث الحالي في تتاوله للكتاب الإلكتروني التفاعلي

$$
\text { تحديداً. }
$$

- تلوعت المجالات التي تتاولتها الدراسات السابقة فمنها: العلوم، والطب، والرحلات المعرفية عبر الويب، والرياضيات، والقراءة، كل هذا التعدد دليل على إمكانية توظيفه في لوني

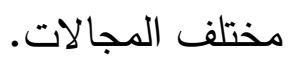
- وظفت الدراسات السابقة المنهج شبه التجريبي والمنهج الوصفي. - طبقت الدراسات السابقة على مراحل تعليمية مختلفة منها: المرحلة الابتدائية، المرحلة المتوسطة، والمرحلة الجامعية. - - طبقت الدراسات السابقة في مجتمعات تعليمية متباينة منها: جمهورية مصر العربية، المملكة العربية السعودية، والأردن، وغزة، والولايات المتحدة الأمريكية، وتايلاند، وتايوان. - أجمعت الدراسات السابقة ضمن هذا المحور على فاعلية الكتاب الإكتروني التفاعلي.

المحور الثاني: القراءة أولاً: تعريف القراءة:

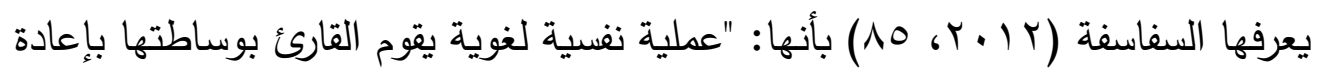
بناء معنى عبر عنه الكاتب في صورة رموز مكتوبة، والقراءة في ضوء ذللك هي عملية استخلاص المعنى من الرمز المكتوب، أو هي أداة اتصال فكري بين القارئ والكاتب من خلا فئ فئه

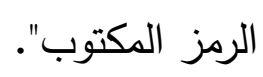

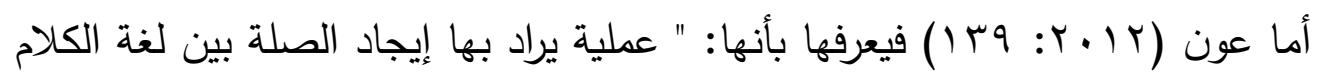
والرمز المكتوب، وتتألف لغة الكلام من المعاني والألفاظ التي تؤدي هذه المعاني، فهي إذاً عملية عضوية نفسية عقلية ". المجلد الثامن- العدد الأول- مسلسل العدد (15)- يناير 2022- الجزء الأول 
يتضح مما سبق أن مفهوم القراءة أصبح يعني تعرف الرمز المكتوب والنطق به وتفسير معناه وفقاً لخبرات القارئ السابقة مع فهمه والتقاعل معه وتوظيفه في المواقف الحياتية التي يمر بها. ثانياً: أهمية القراءة أ. القراءة عامل حاسم في اكتساب الطلاب الخبرات المختلفة والمعارف الخصبة. ب. القراءة تجعل الفرد يتصل بغيره مهما تباعدت بينهما المسافات أو الأزمان. ج. القراءة وسيلة من وسائل التهذيب وغرس الأخلاق الحميدة في نفوس الصغار. د. يقرأ الطلاب القصص والكتب الأخرى غير اللغة العربية. هـ تعد القراءة أهم المواد الدراسية لصلتها الوثيقة بالمواد الأخرى. و. القراءة هي الخطوة الرئيسة المهمة في تعليم اللغات الحية. ز · عن طريق القراءة يتذوق الصغار الأدب والقيم التي تحقق الراحة النفسية. ثالثاً: أهداف القراءة

تتعدد أهداف القراءة وتتنوع وفقاً لنوع القراءة والغرض منها وطبيعة المرحلة التعليمة، ففي المرحلة الابتدائية يتم التركيز على تعرف المقروء والنطق به، وفهم المقروء، والطلاقة القرائية. (الهلالي،

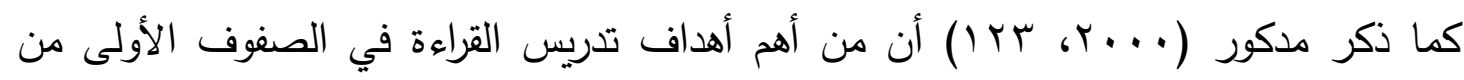
مرحلة التعليم الأساسي ما يأتي:

- اكتساب عادات تعرف الكلمات، كتعرف الكلمة من شكلها، و تعرف الكلمة من تحليل بنيتها و فهم مدلولها، مع التدريب على علامات الترقيم ووظيفتها في القراءة. - - فهم الكلمة، والجملة، والنصوص البسيطة. - - بناء رصيد مناسب من المفردات التي تساعد على فهم القطع التي قد تمتد إلى عدة فقرات. - - تتمية الرغبة والشوق إلى القراءة والاطلاع، والبحث عن المواد القرائية الجديدة. - - سلامة النطق في القراءة الجهرية ومعرفة الحروف وأصواتها، ونطقها، وصحة القراءة. 
رابعاً: أنواع القراءة

تنقسم القراءة من حيث الشكل والأداء إلى نوعين هما: القراءة الصامتة، والقراءة الجهرية، وهما ما يعمد إليه معلم اللغة العربية في تعليم القراءة للصفوف الأولية من مرحلة التعليم الابتدائي. القراءة الصامتة:

ويحصل منها القارئ على المعاني والأفكار دون الاستعانة بعنصر الصوت، فالعين والعقل هما عنصران أساسيان في أداء القراءة الصامتة (جابر، (99 (، بـ)، ويرى الهلالي (10 ( 1 أنها قد تستخدم في تعليم القراءة في الصفوف الأولية من المرحلة الابتدائية بنسبة أقل منها في الصفوف العليا. مميزات القراءة الصامتة:

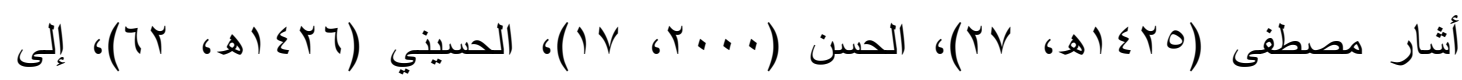
مميزات القراءة الصامتة منها: - زيادة سرعة المتعلم في القراءة مع إدراكه المعاني المقروءة، وتحقيق الفهم. - زيادة قدرة التلميذ على القراءة والفهم في دروس القراءة وغيرها من المواد. - تساعده على تحليل ما يقرأ والتمعن فيه، مع تتمية الرغبة لديه في حل المشكلات. - - القراءة الصامتة من أهم الوسائل التي تحقق للقارئ أهدافاً عديدة لأنها تيسر لله إثباع حاجاته وتنمية ميوله وتزوده بالمعارف الضرورية في حياته.

القراءة الجهرية:

يعرف البجة (Y. . r) القراءة الجهرية بأنها: " العملية التي تتم فيها ترجمة الرموز الكتابية إلى ألفاظ منطوقة، وأصوات مسموعة، متباينة الدلالة حسب ما تحمل من معنى".

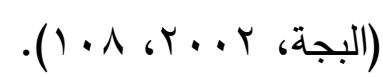

وتلاميذ الصفوف الأولية من المرحلة الابتدائية، يجب تدريبهم على القراءة الجهرية حتى يكتسبوا المهارات القرائية التي تمكنهم (مستقبلاً) من تتاول القراءة الصامتة بكل يسر وسهولة، ولعل ما يؤكد هذا التوجه ما أشار إليه سمك بقوله: يجب العناية بالقراءة الجهرية، وعلى المعلم أن يجعلها أساساً صالحاً لتدريب التلاميذ، حتى يستطيع أن يكثف صعوبات النطق لديهم. (سمك، 1991 (199، (199)

المجلد الثامن- العدد الأول- مسلسل العدد (15)- يناير 2022- الجزء الأول 
الاراسات السابقة المتعلقة بمحور القراءة:

دراسة الغلبان (ع ( ب)، استهدفت معرفة أثر توظيف استراتيجيتين من استراتيجيات

التعلم النشط في تتمية مهارات الفهم القرائي لدى تلميذات الصف الرابع، وقد أظهرت نتائجها أن استراتيجيتي التعلم النشط لهما تأثير كبير في تتمية مهارات الفهم القرائي لدى طلبة الصف الرابع الأساسي.

دراسة جونسون (Johnson, 2014)، هدفت إلى معرفة أثر النشاط التراكمي وعلاقات الأقران على الفهم القرائي ولتحقيق أهداف الدراسة اتبع الباحث المنهج التجربي، وتكونت عينة الدراسة من (Yq ( ) طالباً، وأظهرت نتائج الدراسة أهمية دور الأقران في الفهم القرائي، وإكساب المهارات الاجتماعية بين طالب وآخر •

دراسة أبو الريش (10 (r)، استهدفت الكثف عن أثز استخدام استراتيجيتي (SQ3R) في الفهم القرائي والتحصيل واكتساب المفردات لدى طلبة المرحلة (SNIPS) الأساسية، وتوصلت الدراسة إلى وجود أثر لكلتا الاستراتيجيتين دون فارق بينهما في الفهم القرائي والتحصيل واكتساب المفردات.

دراسة الهلالي (10 ( ب)، هدفت إلى التعرف على فاعلية استخدام برنامج أتقن في تنمية مهارات القراءة والمتمثلة في (تعرف المقروء ونطقه، وفهم المقروء، والطلاقة القرائية) لدى تلاميذ الصف الثاني الابتدائي، وتوصلت تلك الدراسة إلى فاعلية برنامج أتقن في تتمية مهارات القراءة المستهدفة.

دراسة العمرو (10 (Y)، استهدفت تعرف أثر برمجية تعليمية في إكساب مهارات القراءة لأطفال رياض الأطفال، وقد أثبتت النتائج وجود فروق دالة إحصائياً في مستوى أداء أطفال الروضة على اختبار مهارات قراءة الحروف الهجائية يعزى لطريقة التدري، ولصالح الطريقة المحوسبة.

دراسة التتري (T ( ا Y)، استهدفت معرفة أثر توظيف القصص الرقمية في تتمية مهارات الفهم القرائي لاى طلاب الصف الثالث الأساسي، وقد أظهرت النتائج الأثر الإيجابي من توظيف القصص الرقمية في تنمية مهارات الفهم القرائي لدى طلاب الصف الثالث الأساسي. 


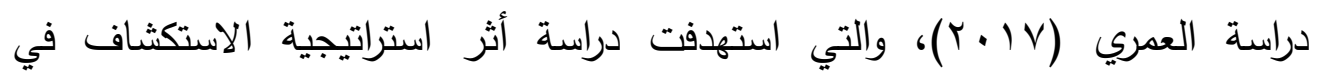

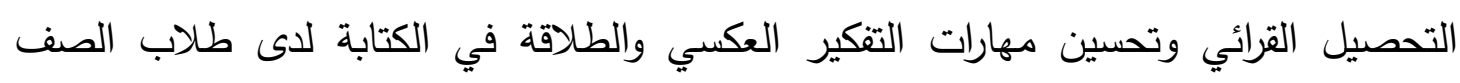
العاشر ، وأظهرت النتائج وجود أثر دال إحصائياً يعود للاستراتيجية المقترحة. وبالنظر إلى الاراسات السابقة نجد الآتي:

- ت ترتبط جميع دراسات هذا المحور مع الدراسة الحالية في تتناولها لمهارة القراءة.

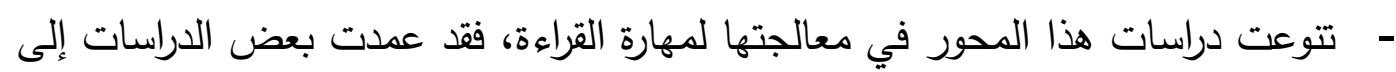
استخدام الاستراتيجيات مثل: لعب الأدوار والتعلم التعاوني، (SNIPS) و (SQ3R)، والاستكثاف، في حين مالت بعض الدراسات إلى استخدم البرامج الدحوسبة أو استخدام

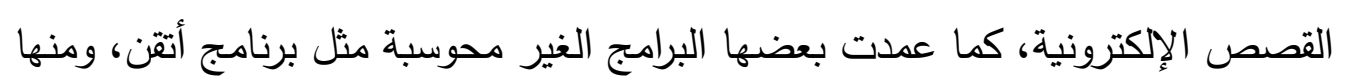
ما اعتمد على الأنشطة مثل النشاط التراكمي وعلاقة الأقران.

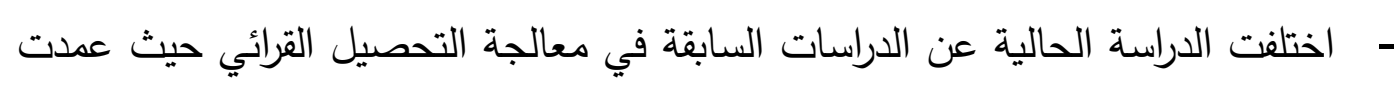

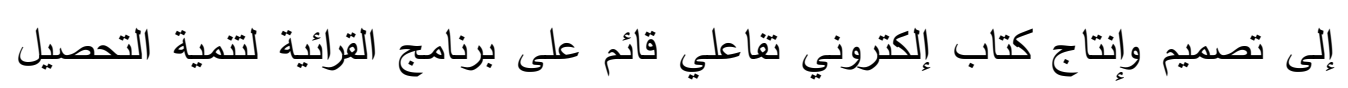
الترائي لدى تلاميذ الصف الثالث الابتدائي. - استخدمت غالبية الدراسات المنهج شبه التجريبي.

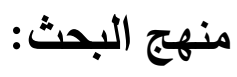

1- المنهج الوصفي والتحليلي، وذلك لتحليل الكتابات في الإطار النظري والدراسات والبحوث التي تناولت الكتاب الإكتروني التفاعلي، والتحصيل القرائي - وتحليل نتائج الدراسة وتفسيرها. r- المنهج شبه التجريبي في الجانب الميداني لهذه الدراسة. حدود البحث:

حدود موضوعية: حصرت الدراسة في موضوع تتمية التحصيل القرائي في الوحدة الأولى من

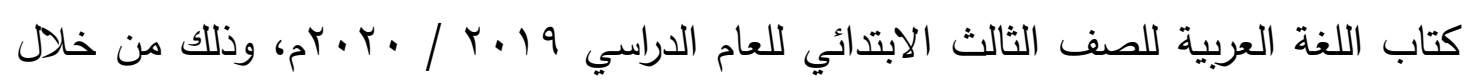
تناولها باستخدام كتاب إلكتروني تفاعلي قائم على برنامج القرائية. حدود مكانية: تم تطبيق الدراسة في إحدى مدارس إدارة كفر صقر التعليمية بمحافظة الشرقية بجمهورية مصر العربية.

المجلد الثامن- العدد الأول- مسلسل العدد (15)- يناير 2022- الجزء الأول 
حدود بثرية: تم تطبيق البحث على عينة ممثلة لمجتمع الدراسة من تلاميذ الصف الثالث الابتدائي بإحدى مدارس كفر صقر بمحافظة الشرقية، كما قام الباحث بتقسيم عينة الدراسة إلى مجموعتين متكافئتين إحداهما تجربية (V \&) تلميذاً، والأخرى ضابطة (Tء ) تلميذاً. حدود زمانية : تم إجراء تجربة البحث خلال الفصل الدراسي الأول من العام الدراسي 9 أ. I / •r.r.r ، حتى يتسنى للقائمين على تجربة البحث تدريب التلاميذ على استخدام الكتاب الإلكتروني المقترح. إجراءات البحث:

سار البحث الحالي وفقاً للخطوات التالية: - دراسة تحليلية للبحوث والدراسات المرتبطة بموضوع البحث العربية منها والأجنبية وذلك بهذف إعداد إطاراً نظرياً وإعداد المحتوى العلمي وتصميم أدوات البحث. - استعراض بعض من نماذج لبرامج متخصصة في تصميم وإنتاج الكتب الإكترونية لتحديد نقاط القوة والضعف فيها بهدف تحديد إمكانية الاستفادة منها في بناء الكتاب الإلكتروني المقترح.

- - تصميم الكتاب الإلكتروني المقترح وفقاً للخطوات التالية: • تحديد الأهداف التعليمية المراد تحقيقها للجانب النظري والعملي للكتاب الإكتروني المقترح ثم عرضها على الخبراء والمحكمين بهدف تقويمها وإخراجها في صورتها النهائية.

إعداد المحتوى التعليمي للكتاب الإلكتروني المقترح في ضوء قائمة الأهداف للوحدة الأولى من الكتاب المدرسي للصف الثالث الفصل الدراسي الأول للعام الدراسي

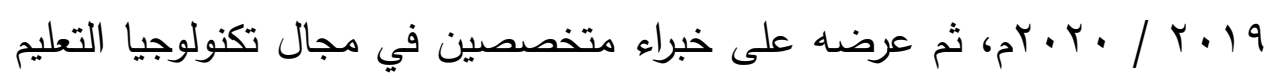
بهدف التحكيم عليه وتعديله وفقاً لآراء السادة الخبراء والمحكمين. وضع النموذج التصميمي للكتاب الإلكتروني المقترح مع مراعاة الأسس والمعايير الخاصة ببناء وتصميم الكتب الإكترونية التعليمية التفاعلية. • إنتاج الكتاب الإكتروني المقترح في صورته النهائية بعد إجراء التعديلات المقترحة وفق آراء السادة الخبراء المحكمين. 
" القيام بتجربة استطلاعية للكتاب الإكتروني المقترح على عينة من التلاميذ للتأكد من صلاحيته ومناسبته لأعمار التلاميذ وخبراتهم وخبرات معلميهم.

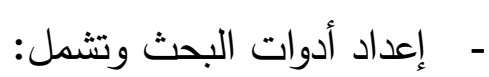

تحديد قائمة الأهداف الخاصة بالوحدة الأولى من منهج اللغة العربية للصف الثالث

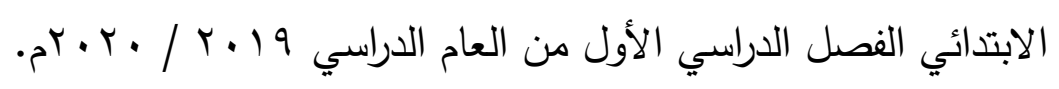

إعداد اختبار تحصيلي للوحدة الأولى من منهج اللغة العربية للصف الثالث الابتدائي

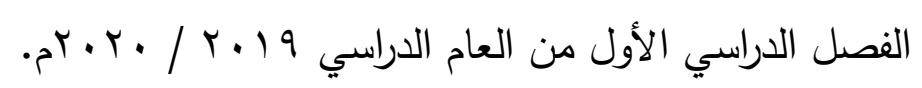

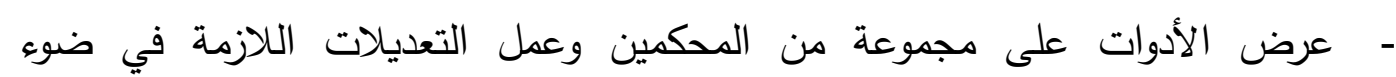

$$
\text { المقترحات وقياس صدق وثبات وموضوعية الأدوات. }
$$

- - إجراء التجربة الاستطلاعية لأدوات القياس بهدف قياس ثبات الأدوات والتعرف على ولى

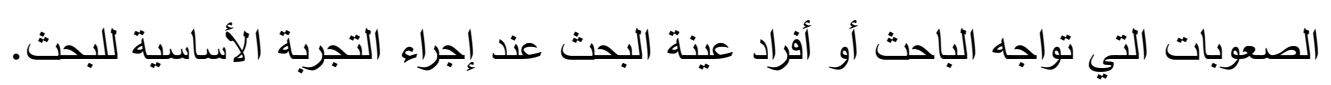

- اختيار عينة البحث من بين تلاميذ الصف الثالث الابتدائي بطريقة عشوائية.

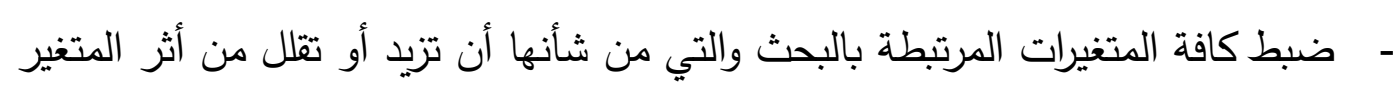

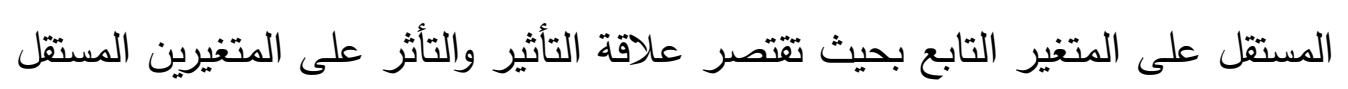
والتابع فقط. - - إجراء التجربة الأساسية للبحث:

$$
\text { • تطبيق الاختبارات على المجموعتين قبلياً. }
$$$$
\text { • التدريس للمجموعة التجريبية باستخدام الكتاب الإلكتروني المقترح. }
$$

" التدريس للمجموعة الضابطة باستخدام الطرق التقليدية. • تطبيق الاختبارات بعدياً على المجموعتين التجريبية والضابطة.

$$
\text { - - مصد البيانات والنتائج التي تم الحصول عليها في جداول. }
$$

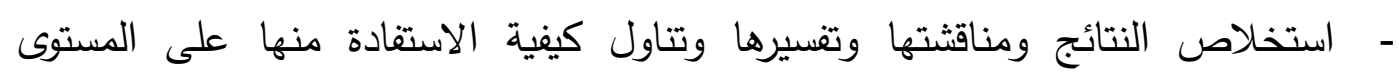
التطبيقي وذلك في ضوء النتائج. - مياغة توصيات البحث والمقترحات لإجراء بحوث مستقبلية. 
أولاً: تصميم وإنتاج مادة المعالجة التجريبية: بعد الاطلاع على الدراسات والأدبيات العربية والأجنبية المعنية بالكتاب الإكتروني مادهي

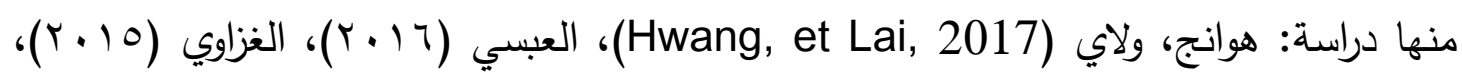
فراي (Frye, 2014) سامريجرونجروج وآخرون (Samrejrongroj, et al, 2014)، ، اعتمد الباحث نموذج التصميم التعليمى العام ADDIE (9 (1))، والذي يتميز بكونه الأساس لجميع نماذج التصميم التعليمي

المرحلة الأولى: التحليل Analysis Phase أ. تحليل الحاجات التعليمية:

انطلاقاً من مشكلة البحث والتي تتمثل في ضعف مستوى التحصيل في القراءة الثفهية لدى بعض تلاميذ الصف الثالث الابتدائي بإدارة كفر صقر التعليمية بصورة لا تحقق الأهداف المرجوة، وبالبحث والتحليل وقع الاختيار على الكتاب الإكتروني التفاعلي القائم على برنامج القرائية.

\section{ب. تحليل الأهداف:}

من أهم الخطوات الإجرائية بعد تحديد الحاجات التعليمية انطلاقاً من مشكلة البحث، تم تحديد الأهداف التعليمية للوحدة الأولى من كتاب اللغة العربية للصف الثالث الابتدائي للفصل

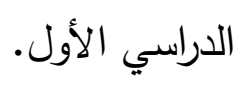
قائمة الأهداف: من الإجراءات التي اتبعها الباحث لإعداد وضبط قائمة الأهداف ما يلي: 1 - تحديد الهُف من القائمة:

يرتبط نجاح الكتاب الإكتروني التفاعلي ارتباطاً وثيقاً بتحديد الأهداف وتصميمها؛ فعلى هديها يتم اختيار الخبرات التعليمية، والأنشطة وطرق التتريس، وتحديد أساليب التقويم وقياس

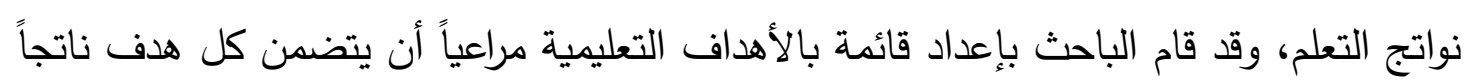
تعليمياً واحداً. r- إعداد الصورة الأولية لقائمة الأهداف: بعد الاطلاع على الأهداف العامة والخاصة لمادة اللغة العربية للصف الثالث الابتدائي

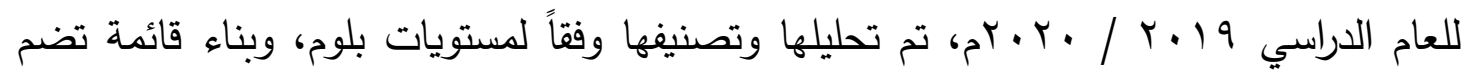
ثلاثين هدفاً.

المجلد الثامن- العدد الأول- مسلسل العدد (15)- يناير 2022- الجزء الأول 
r- التحقق من صدق القائمة:

للتحقق من صدق القائمة تم عرضها على مجموعة من المحكمين ذوي الخبرة المتخصصين في مجال مناهج وطرق تدريس اللغة العربية، وقد أبدى الخبراء رأيهم واقتراح بعض التعديلات جدول (r): جدول رقم (؟) مقترحات المحكمين لتعديل أهداف الكتاب الإكتروني التفاعلي

\begin{tabular}{|c|c|c|}
\hline الهـف بعد التعديل & الهذف قبل التعديل & b \\
\hline يتعرف معاني الدفردات الواردة بالنص & يتعرف معاني المفردات & 1 \\
\hline يتعرف أضرار تراكم القمامة في الحي & يتعرف أضرار تراكم القمامة & r \\
\hline يقدر حب الثاعر للغة العربية الفصحى & يدرك حب الثاعر للغة العربية الفصحى & r \\
\hline يميز أبيات النشيد مسموعاً & يميز النشيد مسموعاً & $\varepsilon$ \\
\hline
\end{tabular}

ع - إعداد قائمة الأهداف في صورتها النهائية:

بعد إجراء التعديلات أصبحت قائمة الأهداف للوحدة الأولى موضوع البحث في

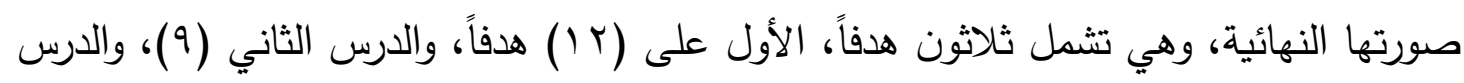
الثالث (9) (9)

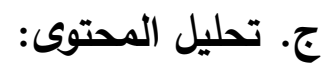
تحليل المحتوى يهدف إلى الوصف الموضوعي والتبويب الكمي لمحتوى الكتاب، وقد تم تحليل محتوى الوحدة الأولى من كتاب اللغة العربية للصف الثالث الابتدائي الفصل الدراسي

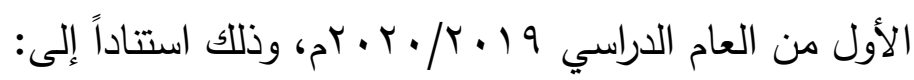
الاطلاع على توصيف المقرر . الاطلاع على استراتيجيات وأنشطة القرائية للصف الثالث. الاطلاع على نواتج التعلم لهنهج اللغة العربية للصف الثالث الابتدائي الفصل الدراسي الأول. الخبراء والمتخصصون في مجال اللغة العربية، وبرنامج القرائية.

المرحلة الثانية: التصميم Design Phase

تم في هذه المرحلة وضع تصور لمواصفات الكتاب الإلكتروني التفاعلي من خلال: أ. معايير تصميم وإنتاج الكتاب الإكتروني التفاعلي: من الإجراءات التي اتبعها الباحث لإعداد قائمة معايير تصميم وإنتاج الكتاب الإككتروني. المجلد الثامن- العدد الأول- مسلسل العدد (15)- يناير 2022- الجزء الأول 


$$
1 \text { ـ تحديد الهاف من قائمة معايير تصميم وإنتاج الكتاب الإكتروني: }
$$

فقد استهدف البحث الحالي إعداد قائمة بالمعايير التي يجب توافرها في تصميم وإنتاج

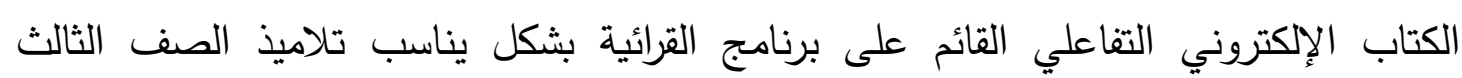
الابتدائي. r. إعداد الصورة الأولية لقائمة معايير تصميم وإنتاج الكتاب الإكتروني: بعد الاطلاع على الدراسات والأدبيات العربية والأجنبية المعنية بهذا الثأن منها دراسة:

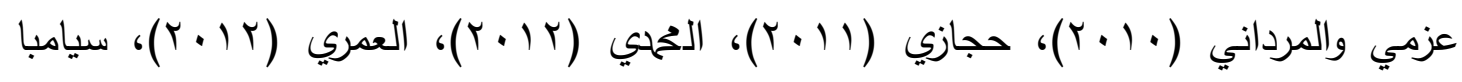
(Ciampa , 2012) (Hwang , et Lai . 2017) الإلكتروني التفاعلي، وقد اشتملت في صورتها الأولية على محورين هما: المعايير التربوية والتعليمية، والمعايير الفنية والتكنولوجية ، ينحدر منها (أحد عشر) معياراً رئيسياً، و(خمسون) معياراً فرعياً. r. التحقق من صدق قائمة معايير تصميم وإنتاج الكتاب الإكتروني: للتحقق من صدق القائمة تم عرضها على مجموعة من المحكمين ذوي الخبرة المتخصصين في مجال تكنولوجيا التعليم للتأكد من صدق كل معيار رئيسياً كان أو فرعياً، ومدى ارتباطه بالمحور الذي يندرج تحته، وقد أبدى الخبراء أيهم فيها واقتراح بعض التعديلات كنيات من حيث: الإضافة، الحذف، الاستبدال أو إعادة الصياغة. ؛. . إعداد قائمة معايير تصميم وإنتاج الكتاب الإكتروني في صورتها النهائية: بعد إجراء التعديلات أصبحت القائمة تشتمل على محورين أحدهما: المعايير التربوية

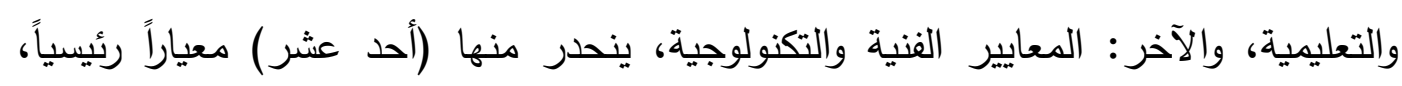

$$
\text { و (اثثين وخمسون) معياراً فرعياً. }
$$

ب. تصميم السيناريو (Story Board) للكتاب الإكتروني التفاعلي:

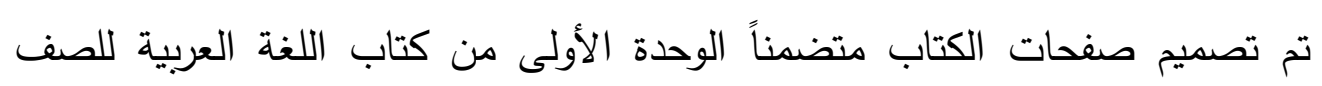

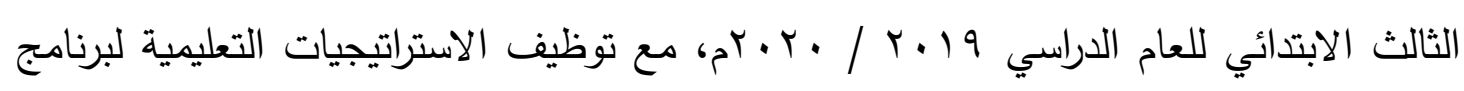
القرائية وخاصة ما يتعلق بالطلاقة في القراءة الثفهية، وفهم المقروء والمسموع، بشكل يسمح

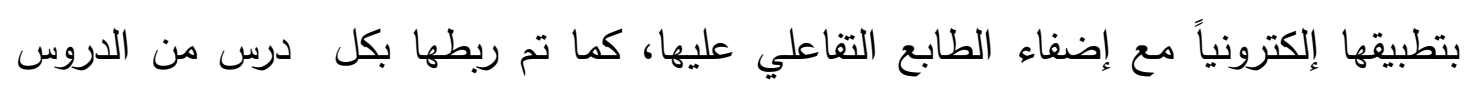
المجلا الثامن- العدد الأول- مسلسل العدد (15)- يناير 2022- الجزء الأول 
الثلاثة للوحدة الأولى، ومايتضمنه من أهداف وأنشطة وتدريبات ومترادفات وتهيئة، وفي ضوء تحليل المحتوى وتجزئته لعناصر أولية يسهل التفاعل معها، وتشكل مجموعة من الخبرات

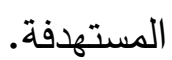

ج. وسيط النشر: تم اختيار القرص الدمدج كوسيط للنشر على أجهزة الحاسب المكتبية والمحمولة ليناسب طبيعة التجهيزات التقنية في المدارس الرسمية، فهو الأنسب لتلاميذ هذه

$$
\text { المرحلة. }
$$

د. - إختبار التحصيل المعرفي:

تم بناء الاختبار التحصيلي المعرفي وفقاً للإجراءات التالية: 1- تحديد الهدف من الاختبار التحصيلي المعرفي:

هدف الاختبار إلى الوقوف على درجة معرفة التلاميذ لمحتوى الوحدة الأولى من كتاب

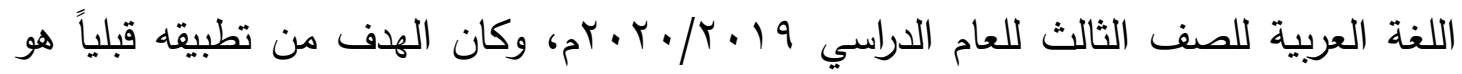
التأكد من تكافؤ المجموعتين (التجريبية، والضابطة) فيما يخص المعارف والمهارات السابقة لديهم، أما الهدف من تطبيقه بعدياً فهو مقارنة تحصيل المجموعتين (التجريبية، والضابطة) للوقوف على أثر المعالجة التجريبية (الكتاب الإكتروني التفاعلى) والذي تعرضت له المجموعة التجريبية دون الضابطة.

ץ- تحديد الأهداف السلوكية الإجرائية لاختبار التحصيل المعرفي:

تم إعداد قائمة الأهداف السلوكية الإجرائية للوحدة الأولى وفقاً للمستويات بلوم المعرفية

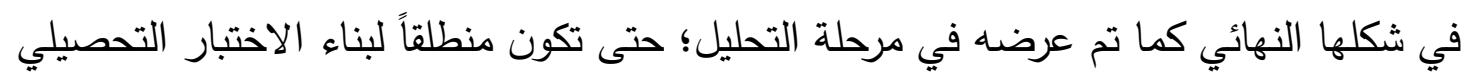

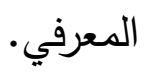
r- بناء جدول المواصفات: تم بناء جدول مواصفات اختبار التحصيل المعرفي وفقاً لما يلي:

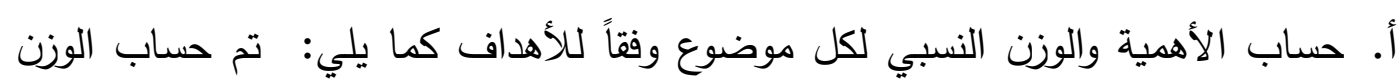

النسبي لكل موضوع وكانت النتيجة كما هو موضح في جدول (r) 
مجلة دراسات وبحوث التربية النوعية

جدول (ץ) حساب الأهمية والوزن النسبي لكل موضوع وفقاً للأهداف.

\begin{tabular}{|c|c|c|}
\hline الوزن انسبي & الأهداف & الموضوعات التعليمية \\
\hline$\% \varepsilon$. & ir & الموضوع الأول \\
\hline$\%$ \%. & 9 & الموضوع الثاني \\
\hline$\% r$. & 9 & الموضوع الثالث \\
\hline$\% 1 \ldots$ & $r$. & المجموع \\
\hline
\end{tabular}

ب. حساب الأهمية والوزن النسبي لكل مستوى من مستويات الأهداف:

بعد صياغة قائمة الأهداف النهائية، تم حساب الأهمية والوزن النسبي لكل مستوى من مستويات بلوم المعرفية (التذكر ، الفهم، التطبيق، التحليل، التقييم، الابداع ) كالتالي: جدول (؛ ) جدول المواصفات حسب الأهمية لكل مستوى من مستويات الأهداف

\begin{tabular}{|c|c|c|c|c|c|c|c|}
\hline المجموع & تقييم & إبداع & تحليل & تطبيق & فهم & تذكر & الموضوعات التعليمية \\
\hline Ir & 1 & r & r & r & r & r & الموضوع الأول \\
\hline 9 & 1 & 1 & r & r & 1 & 1 & الموضوع الثاني \\
\hline 9 & r & 1 & r & r & 1 & 1 & الموضوع الثالث \\
\hline r. & $\varepsilon$ & $\varepsilon$ & 9 & $v$ & $\varepsilon$ & - & مجموع كل مستوى \\
\hline
\end{tabular}

كما تم حساب الوزن النسبي للأهداف وكانت النتيجة كما هو موضح في جدول (0) 
مجلة دراسات وبحوث التربية النوعية

جدول (•) الوزن النسبي للأهداف

\begin{tabular}{|c|c|c|c|c|c|c|c|}
\hline 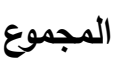 & تقييم & إبداع & تحليل & تطبيق & فهم & تذكر & الموضوعات التعليمية \\
\hline $40 \%$ & $3 \%$ & $7 \%$ & $7 \%$ & $7 \%$ & $7 \%$ & $10 \%$ & الموضوع الأول \\
\hline $30 \%$ & $3 \%$ & $3 \%$ & $7 \%$ & $10 \%$ & $3 \%$ & $3 \%$ & الموضوع الثاني \\
\hline $30 \%$ & $3 \%$ & $7 \%$ & $7 \%$ & $7 \%$ & $3 \%$ & $3 \%$ & الموضوع الثالث \\
\hline $100 \%$ & $10 \%$ & $17 \%$ & $20 \%$ & $23 \%$ & $13 \%$ & $17 \%$ & المجموع \\
\hline
\end{tabular}

ع - صياغة مفردات وتعليمات الاختبار : تمت صياغة فقرات الاختبار بالثكل الموضوعي في

ضوء الأهداف السلوكية الإجرائية، وقد تكون الاختبار من (•r) سؤالاً كما يلي:

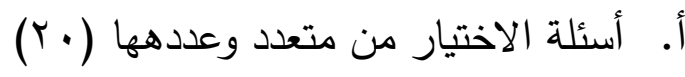

ب. بأسئلة الصواب والخطأ وعددها (r)

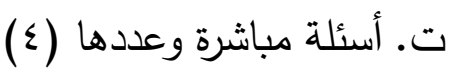

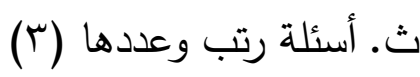

ه- تحديد عدد الأسئلة التي ترتبط بكل مستوى كما هو مبين بجدول (†): 
جدول (†) عدد الأسئلة التي ترتبط بكل مستوى

\begin{tabular}{|c|c|c|c|c|c|c|c|c|c|c|c|c|c|c|}
\hline \multirow{2}{*}{ النسبي } & \multirow{2}{*}{ p } & \multicolumn{2}{|c|}{ تقييم } & \multicolumn{2}{|c|}{ إبداع } & \multicolumn{2}{|c|}{ تحليل } & \multicolumn{2}{|c|}{ تطبيق } & \multicolumn{2}{|c|}{ فهم } & \multicolumn{2}{|c|}{ تذكر } & \multirow{2}{*}{ التعليمية } \\
\hline & & | أرقامها & العدد & أرقامها & العدد & أرقامها & العدد & أرقامها & العدد & أرقامها & العدد & أرقامها & العدد & \\
\hline $40 \%$ & ir & أولاً: د & 1 & 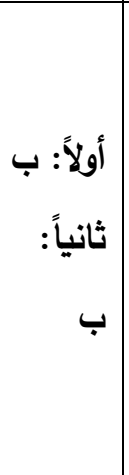 & r & جامساً: & r & ثام ثالثاً: & r & 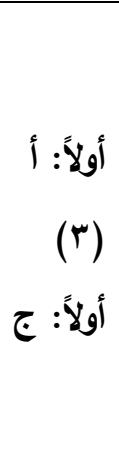 & r & 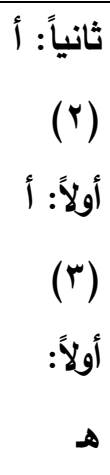 & $r$ & الأول \\
\hline $30 \%$ & 9 & |أ سادساً: & 1 & $\begin{array}{r}\text { ثالتاً: } \\
\text { ح }\end{array}$ & 1 & ثانياً: & r & ' & $r$ & دادساً: & 1 & $\begin{array}{r}\text { أولاً: } \\
\text { (1) }\end{array}$ & 1 & الثاني \\
\hline $30 \%$ & 9 & $\begin{array}{r}\text { ثالثاً: } \\
\text { ثالثاً: } \\
\text { ثأث }\end{array}$ & r & لـ & 1 & دابعاً: & $r$ & رابعاً: أ & 1 & ثالثاً: أ & 1 & ز ثالثاً: & 1 & الثالث \\
\hline \multicolumn{2}{|c|}{$r}$. & \multicolumn{2}{|l|}{$\varepsilon$} & \multicolumn{2}{|l|}{$\varepsilon$} & \multicolumn{2}{|c|}{ v } & \multicolumn{2}{|c|}{1} & \multicolumn{2}{|c|}{$\varepsilon$} & \multicolumn{2}{|c|}{0} & المجموع \\
\hline \multicolumn{2}{|c|}{$100 \%$} & \multicolumn{2}{|c|}{$10 \%$} & \multicolumn{2}{|c|}{$17 \%$} & \multicolumn{2}{|c|}{$20 \%$} & \multicolumn{2}{|c|}{$23 \%$} & \multicolumn{2}{|c|}{$13 \%$} & \multicolumn{2}{|c|}{$17 \%$} & النسبي \\
\hline
\end{tabular}

1 - 1 - صياغة تعليمات الاختبار:

تمت صياغة تعليمات الاختبار بصورة بسيطة وواضحة للتلاميذ، وقد روعي عند

الصياغة توضيح (الهذف من الاختبار، عدد مفردات الاختبار، زمن الإجابة، الدرجة الكلية

للاختبار ، طرق الإجابة على أسئلة الاختبار). 
V - Vقدير درجات التصحيح لأسئلة الاختبار : تم تقدير الإجابة الصحيحة لكل سؤال بدرجة واحدة والخطأ بصفر درجة؛ لتصبح

$$
\begin{aligned}
& \text { الدرجة الكلية للاختبار (• (ץ) درجة. } \\
& \text { ^- صدق الاختبار: }
\end{aligned}
$$

من خلال عرضه على المحكمين لمعرفة آرائهم حول تقدير الاختبار من حيث: (مدى ملاءمة الاختبار للأهداف المحددة - الحكم على الصياغة اللغوية والعلمية - مناسبة المفردات للمستويات المحددة للاختبار - دقة صياغة مفردات الاختبار - التعديل المقترح لبنود الاختبار)، وتم إجراء التعديلات المقترحة على الاختبار التحصيلي في ضوء آراء الدحمين، وأصبح الاختبار جاهزاً لإجراء الدراسة الاستطلاعية.

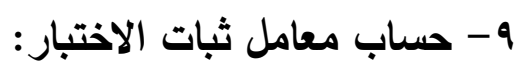

المقصود بثات الاختبار هو أن يعطى الاختبار نفس النتائج إذ أعيد تطبيقه على نفس الأفراد في نفس الظروف، والهدف من قياس ثبات الاختبار هو معرفة مدى خلو الاختبار من

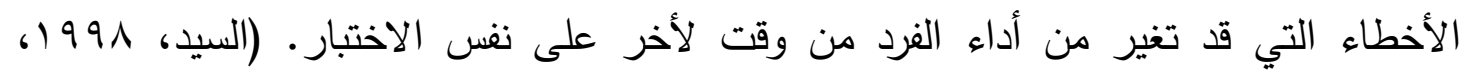
(oro

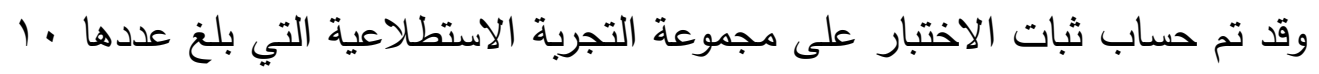

تلاميذ من تلاميذ الصف الثالث الابتدائي، وذلك بعد تطبيق الاختبار التحصيلي على أفراد العينة الاستطلاعية تطبيق أول ثم تطبيقه تطبيق ثاني بعد أسبوعين من التطبيق الأول، ثن حساب معامل ارتباط سبيرمان Spearman Correlation بين درجات التطبيق الأول ودرجات التطبيق الثاني باستخدام برنامج ( SPSS ).

المجلد الثامن- العدد الأول- مسلسل العدد (15)- يناير 2022- الجزء الأول 


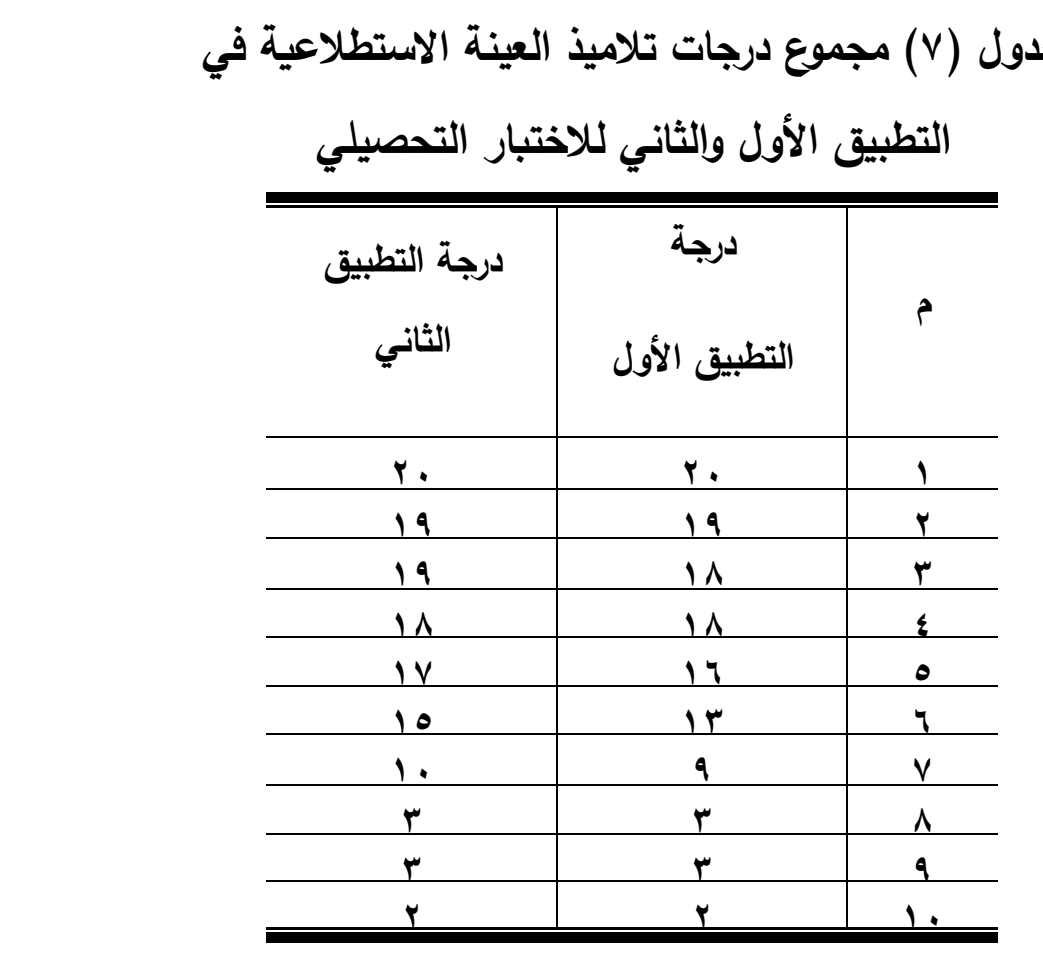

جدول (^) حساب معامل ارتباط سبيرمان بين درجات تلاميذ العينة الاستطلاعية

\begin{tabular}{|c|c|}
\hline الاحتمال & معامل ارتباط سبيرمان \\
\hline$\cdot, \cdot$ &., 991 \\
\hline
\end{tabular}

ويتضح من جدول (^) أن معامل الارتباط بين درجات تلاميذ العينة الإستطلاعية في

التطبيق الأول والثاني للاختبار التحصيلى بلغ (199. •)، أي أن الارتباط بين درجات التطبيق الأول ودرجات التطبيق الثاني للاختبار التحصيلى ارتباط موجب جزئي، وتم حساب معامل ثبات الاختبار من معامل الارتباط (السيد، 991 (، OrA): واتضح أن معامل الثبات للاختبار قد بلغ (990, •) وهذة النتيجة تدل على ثبات عالي للاختبار التحصيلى بنسبة (9,0 \% \%)، وهذا يعنى خلو الاختبار من الأخطاء التى يمكن أن تغير من أداء التلميذ من وقت لآخر، ومن ثم يمكن الوثوق والاطمئنان إلى النتائج التي يتم الحصول عليها عند تطبيقه. • 1 - حساب معامل السهولة لكل مفردة من مفردات الاختبار التحصيلي: معامل السهولة هو نسبة عدد الإجابات الصحيحة إلى عدد الإجابات الصحيحة والخاطئة في كل مفردة، وقد تم حساب معامل السهولة لكل مفردة، وتراوحت معاملات السهولة لدفردات 
الاختبار بين • ؛, · : . ،, · ، وهى قيم مناسبة لمعاملات السهولة لأنها تقع داخل الفترة المغلقة [

$$
\cdot[\cdot, \wedge \cdot-\cdot, r \cdot
$$

11 - حسـاب معامـل السـهولة المصحح مـن أثر التخمين لكل مفردة مـن مفردات الاختبـار

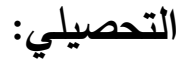

وتتأثر مفردات الاختبارات التي تبنى على اختيار إجابة واحدة من بديلين أو بدائل

متعددة بالتخمين ويزداد أثر هذا التخمين كلما قل عدد الاحتمالات المحددة لكل مفردة، ويقل أثره كلما زاد هذا العدد، ويبلغ التخمين أقصاه عندما يصل هذا العدد إلى احتمالين، ويضعف أثره عندما يصل إلى ستة احتمالات (فرجون، ب999 1، r. (1 : ؛ • ()، وقد قام الباحث بحسـاب معامل السهولة المصحح من أثر التخمين لكل مفردة من مفردات الاختبار باستخدام المعادلة

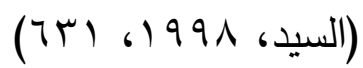

وقد اعتبرت مفردات الاختبار التي بلغ معامل سهولتها (•^ر, • فأكثر) مفردات شديدة السهولة، ولذا يجب حذفها إلا إذا كانت تقيس معلومات مهمة أساسية، واعتبرت مفردات الاختبار التي بلخ معامل سهولتها (• r, • فأقل) مفردات شديدة الصعوبة ولذا يجب حذفها، إلا إذا كان

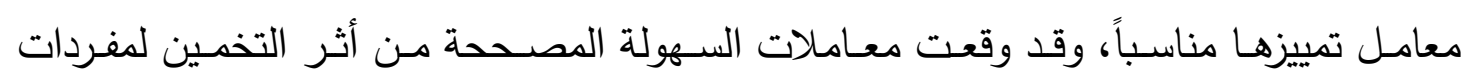

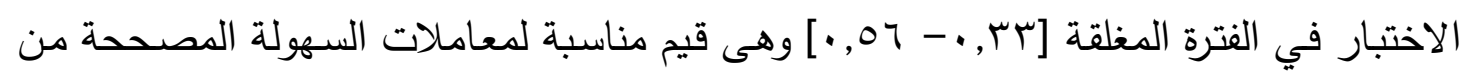

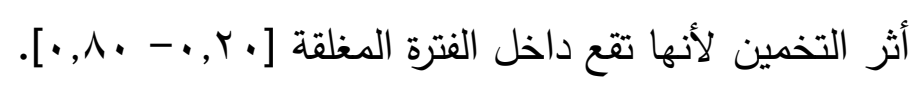
r ا - حساب معامل التمييز لكل مفردة من مفردات الاختبار التحصيلي: يعبر معامـل التمييز عـن قدرة المفردة على التمييز بين التلميذ المتـاز والتلميذ

الضعيف، ولحساب معامل التمييز لكل مفردة قام الباحث باتباع الخطوات التالية:

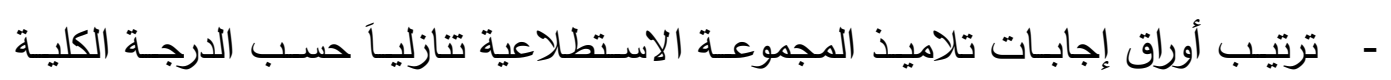
الحاصل عليها التلميذ في الاختبار. - تقسيم درجات تلاميذ المجموعة الاستطلاعية إلى طرفين علوي وطرف سفلي، بحيث يتألف القسم العلوي من الدرجات التي تكون نسبة بr\% من الطرف الممتاز ، ويتألف الطرف السفلي من الدرجات التي تكون نسبة rr\% من الطرف الضعيف.

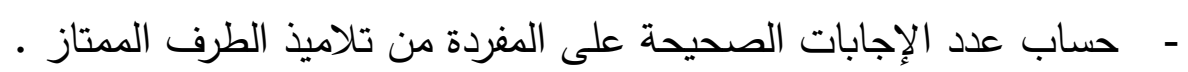

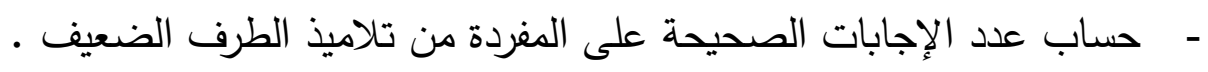


ثم حساب معاملات التمييز لمفردات الاختبار وذلك باستخدام طريقة الفروق الطرفية وذلك من

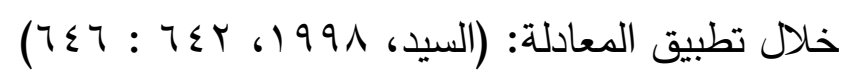
ويتضح من النتائج التي تم التوصل إليها أن معاملات التمييز لمفردات الاختبار

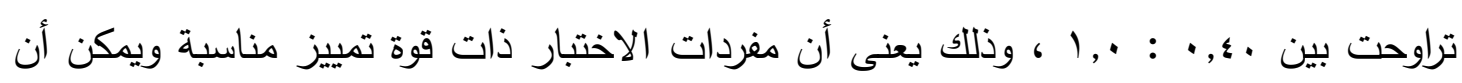
تميز بين التلميذ الممتاز والتلميذ الضعيف. با - تحديد زمن الاختبار التحصيلي: تم حساب زمن الاختبار التحصيلي، وذلك بقسمة مجموع الزمن الذي استغرقه أسرع تلميذ من تلاميذ العينة الاستطلاعية في الإجابة على مفردات الاختبار ، والزمن الذي استغرقه أبطأ تلميذ التئي

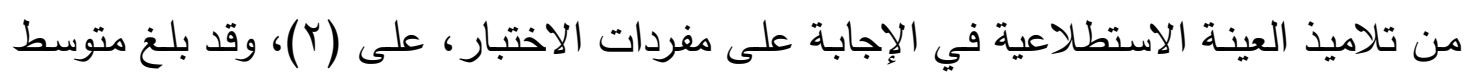
زمن الاختبار التحصيلي (• (7) دقيقة.

ء أ- وضع الاختبار التحصيلي في صورته النهائية: بعد الاطلاع على آراء المحكمين والعمل بها، والتأكد من صدق الاختبار وثباته،

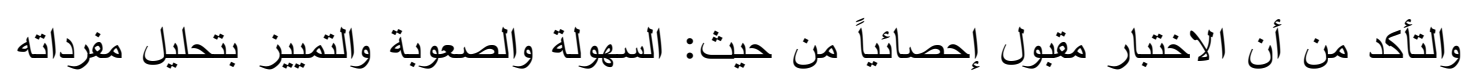

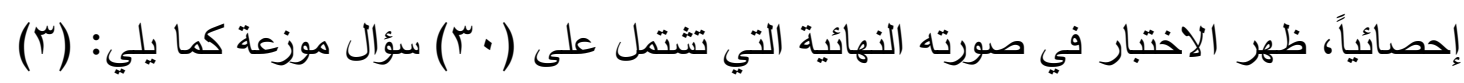

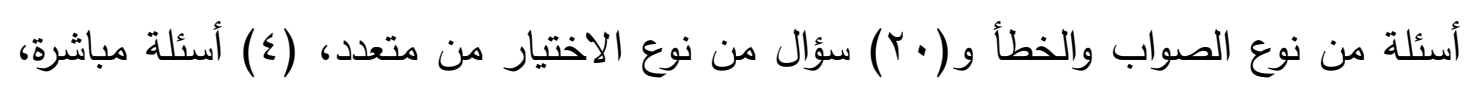
(r) أسئلة من نوع الترتيب، والنهاية العظمى للدرجات (·r) درجة، وبذلك أصبح الاختبار التحصيلي صالحاً للتطبيق على عينة البحث.

المرحلة الثالثة: التطوير Development ا ـ تطوير محتوى الكتاب الإلكتروني التفاعلي: أ. تطوير السيناريو (story board) الذي تم تحريره للكتاب الإلكتروني المقترح، وهي المرحلة الأصعب والأكثر جهاً ووقتاً؛ وذلك لمراعاة طبيعة التلميذ في هذه المرحلة العمرية. ب. تم استخدام برنامج (Adobe Photoshop CS6) في تصميم وإنتاج صفحات الكتاب والغلاف وتجهيز الصور الثابتة وحفظها بامتداد (JPG \& PNG)، واستخدامه كذلك في تجهيز صور ومشاهد فيلم الرسوم المتحركة الذي تم إنتاجه باستخدام برنامج .(Adobe Flash CS6) 
ج. تم استخدام برنامج (Adobe Photoshop CS6)، وبرنامج (Adobe Flash CS6) أيضاً في تصميم وإنتاج الهيكل التصميمي لصفحات الكتاب، وشاشات الشرح التفاعلية

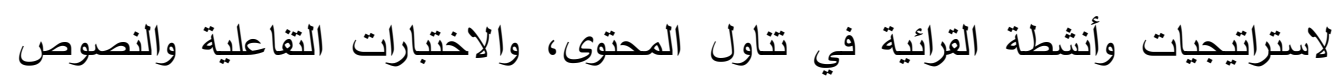
المقروءة والمسموعة. د. تم استخدام برنامج (Adobe Audition CS6) لتسجيل ومعالجة ملفات الصوت. r. الإخراج النهائي للكتاب الإلكتروني التفاعلي: تم تجميع صفحات الكتاب التفاعلى وما تم تطويرة من ملفات: النصوص والصوت والرسوم المتحركة والاختبارات التفاعلية بواسطة برنامج Kvisoft Flipbook Maker Pro وتم إخراج الكتاب بصيغة الملف التنفيذي (EXE) كما تم استخراج نسخة (HTML5) للأجزة المكتبية والمحمولة، الملف المضغوط (ZIP) المتوافق مع نظام أندرويد.

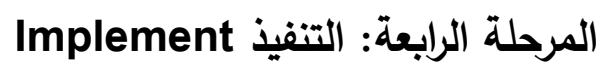

ا. إتاحة الكتاب الإكتروني التفاعلي عبر الوسيط: تم برمجة محتوى الكتاب التفاعلى

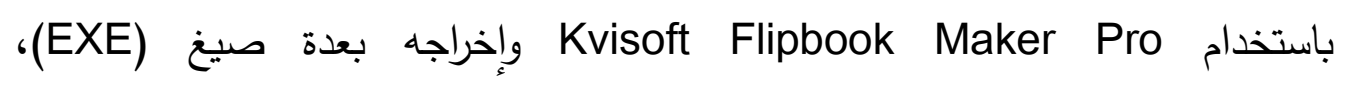
(HTML5))، والملف المضغوط (ZIP)، تمهيداً لتطبيق وتقويم الكتاب الإكتروني التفاعلي على الأجهزة الوسيطة. r. تطبيق الكتاب الإكتروني التفاعلي: تم إخضاع الكتاب الإلكتروني التفاعلي للتجارب في ظروف مماثلة للتجربة الأساسية مع الأخذ في الاعتبار انقطاع التيار الكهربائي أو الوبري انقطاع الانترنت. - إجراء التجارب الأولية على المستويين الفردي والجماعي بهدف كثف وتنقيح الأخطاء الأولية مثل: تعديل عمل بعض الروابط، وضبط الصوت والحركة في بعض المشاهد. إجراء التجربة على مجموعة متتوعة من أجهزة الحاسب الآلي بنظام تشغيل ( Windows

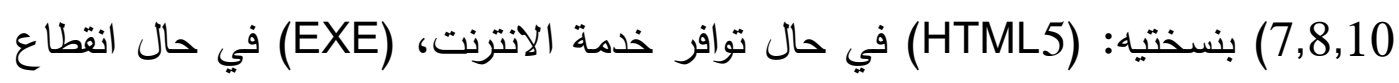
خذمة الانترنت، كذللك تم التجريب باستخدام السبورة التفاعلية (Smart board)، كذلك تم التجريب على أجهزة الحاسب المحمولة (Lab Top) في حال انقطاع التيار الكهربائي وهذه الأجزة متاحة بمعامل الحاسب الآلي بالمدارس الرسمية. 
Evaluate المرحلة الخامسة: التقويم

تهدف مرحلة التقويم إلى إخضاع الكتاب الإكتروني التقاعلي للتحكيم والدصادقة وتعديله وتتقيحه ثم تجريبه وصولاً لإعداد الصورة النهائية للكتاب الإلكتروني المقترح من خلال: ا ـ تقويم جوانب التعلم لمحتوى الكتاب الإكتروني التفاعلي: أ. التحكيم والمصادقة: تم عمل نسخ (EXE) من الكتاب الإكتروني التفاعلي على أقراص ومرفق مع كل قرص خطاب تحكيم بهدف عرضه على المحكمين الخبراء في مجال تكنولوجيا التعليم؛ لتحكيمه، وإبداء آرائهم في مدى صلاحيته. ب. التعديل والتتقيح: تم إجراء بعض التعديلات التي أوصى بها المحكمون (إجراء بعض فئل التعديلات على شكل التصميم). ثانياً: التجربة الاستطلاعية للبحث:

تمت التجربة الاستطلاعية على مجموعة من تلاميذ الصف الثالث الابتدائي بإدارة كفر

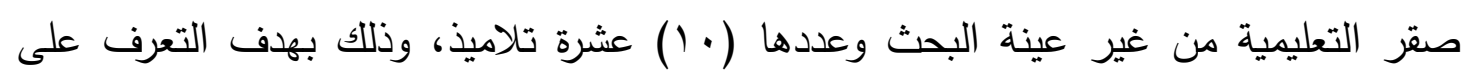
الصعوبات التي قد تواجه الباحث أثناء التجربة الأساسية للبحث والتأكد من الكفاءة الداخلية للكتاب الإكتروني التفاعلي والتحقق من ثبات الاختبار التحصيلي، وقد كثفت التجربة الاستطلاعية عن ثبات الاختبار التحصيلي، كما كثفت عن صلاحية الكتاب الإكتروني التفاعلي القائم على برنامج القرائية.

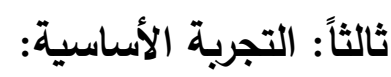
أ. التطبيق القبلي لأدوات القياس: - تدريب تلاميذ المجموعتين التجريبية والضابطة على طرق التطبيق والإجابة على أسئلة اختبار التحصيل المعرفي الإكتروني بالتدريب على اختبار آخر مختلف من حيث المحتوى . - تطبيق الاختبار التحصيلي الإكتروني، لقياس الجانب المعرفي قبلياً. ب. اختبار تكافؤ تلاميذ المجموعتين الضابطة والتجريبية في المستوى القبلي للتحصيل

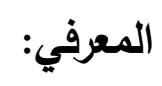


للتأكد من تكافؤ المجموعتين الضابطة والتجريبية في المستوى القبلي للتحصيل المعرفي، قام الباحث بتحليل نتائج التطبيق القبلى لاختبار التحصيل المعرفي إحصائياً، ثم تم استخدام اختبار التكافؤ بين العينات المستقلة. “Levene's Test” لتحديد مدى تكافؤ المجموعتين الضـابطة والتجريبية في المستوى القبلي " لئي للتحصيل المعرفي "Test of Homogeneity of Variances" باستخدام برنامج التحليل

الإحصائي (SPSS). (2)

جدول (9) نتائج اختبار Levene's Test لاختبار تكافؤ المجموعتين الضابطة والتجريبية في المستوى القبلي للتحصيل المعرفي

\begin{tabular}{|c|c|c|c|}
\hline مستوى الدلالة & درجات الحرية (ץ) & درجات الحرية (1) & إحصائى الإختبار \\
\hline r & 91 & 1 & •, rIV \\
\hline
\end{tabular}

ويوضح جدول (9) أن قيمة مستوى الدلالة تساوى بـ T,، وهى أكبر من مستوى

الدلالة المعنوية ه .., · ، وبالتالي نقبل فرض تكافؤ المجموعتين الضابطة والتجريبية في المستوى القبلي للتحصيل المعرفي، بمعنى أن أى فروق تظهر بعد التجربة في مستوى للتحصيل المعرفي، تعود إلى اختلاف المتغيرات المستقلة، وليست إلى اختلافات موجودة بين المجموعتين الضابطة والتجريبية.

Independent - Samples كما استخدام الباحث اختبار (ت) لعينتين مستقلتين ه.Test ، للتعرف على الفروق بين متوسطي درجات طلاب المجموعتين الضابطة والتجريبية في التطبيق القبلي لاختبار التحصيل المعرفي، وكانت النتائج على النحو التالى:

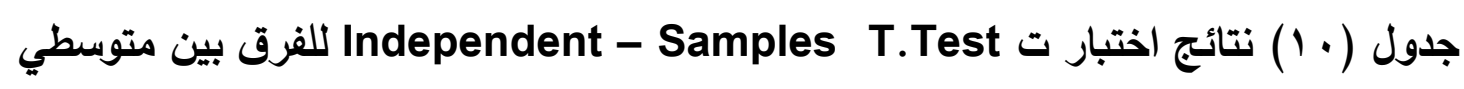
درجات طلاب المجموعتين الضابطة والتجريبية فى التطبيق القبلي لاختبار التحصيل المعرفي

\begin{tabular}{|c|c|c|c|c|c|c|c|}
\hline الدلادة & مستوى الدلالة & قالمحسوبة "ت & لدرجات & المعياري & الحسوسط & العدد & المجموعة \\
\hline غير & \multirow{2}{*}{$\cdot, 9 \leqslant 9$} & \multirow{2}{*}{ צ } & \multirow{2}{*}{91} & $\varepsilon, \cdot \varepsilon$ & $v, \leqslant 0$ & $\leq 4$ & ضابطة \\
\hline دالة & & & & $r, \wedge r$ & $v, \varepsilon$. & $\varepsilon V$ & تجريبية \\
\hline
\end{tabular}

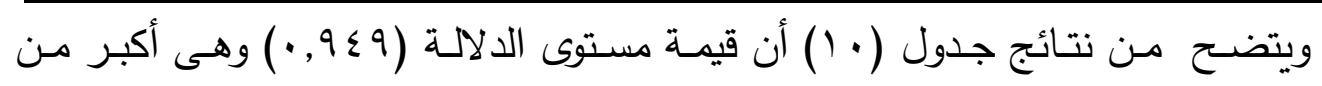

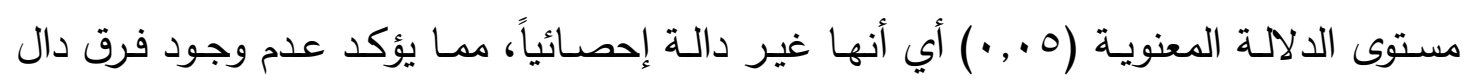
المجلد الثامن- العدد الأول- مسلسل العدد (15)- يناير 2022- الجزء الأول 
إحصائياً عند مستوى الدلالة (0 ., •) بين طلاب المجموعتين التجريبية والضـابطة، في درجات التطبيتق القبلي لاختبـار التحصيل المعرفي، وهذا يؤكد تكـافؤ طـلاب المجمـوعتين التجريبيـة والضـابطة في مستوى التحصيل المعرفي قبل إجراء التجربـة، بمعنى أن أى فروق تظهر بعد التجربـة في مسـتوى التحصيل المعرفي، تعـود إلى اختلاف المتغيـرات المستقلة، وليسـت إلى اختلافات موجودة بين طلاب المجموعتين التجريبية والضابطة. ويوضح شكل (r) متوسطي درجات المجموعتين الضابطة والتجريبية في القياس القبلي لمستوى التحصيل المعرفي.

\begin{tabular}{|c|c|}
\hline 8.00 & \\
\hline 6.00 & متوسط مستوى التحصيل القبلى \\
\hline 4.00 & للمجموعة التجريبية \\
\hline 2.00 & للمجمو عة الضابطة \\
\hline 0.00 & \\
\hline
\end{tabular}

شكل (r) متوسطي درجات المجموعتين الضابطة والتجريبية في القياس القبلي لمستوى التحصيل المعرفي

نتائج البحث وتفسيرها والتوصيات والمقترحات:

يعرض هذا الجزء الإحصاء الوصفي لمتغيرات البحث، كما يتناول الإجابة عن أسئلة البحـث، واختبـار صـحة الفـروض البحثيـة، كـل ذلـك في ضـوء التصـميم التجريبـي للبحـث، وباستخدام برنامج التحليل الإحصـائي الثهير (SPSS22)، وقد تم استخدام اختبار (ت) (T) test" للمتغير المستقل في المتغير التابع، فضـلاً عن مناقشـة نتائج البحث (ES) (Effect Size) وتفسيرها، بالإضافة إلى مجموعة من التوصيات والمقترحات. أولاً: للإجابة على السؤال الأول للبحث والذي نص على: ما صورة الكتاب الإكتروني التفاعلي القائم على برنامج القرائية لتنمية التحصيل القرائي لاى تلاميذ الصف الثالث الابتدائي؟ 
تم اتباع نموذج التصميم العام (ADDIE)، وصولاً للصورة النهائية للكتاب، وقد تم تتاول كل ذلك بالتوضيح في الجزء الخاص بالإجراءات في هذا البحث، وبناء على ذلك فقد تمت الإجابة عن

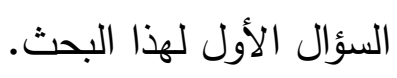
ثانياً: للإجابة على السؤال الثاني للبحث والذي نص على على ما أثر كتاب إلكتروني تفاعلي قائم على برنامج القرائية في تنمية مستوى التحصيل القرائي في اللفة العربية لاى تلاميذ الصف الثالث الابتدائي؟ قام الباحث بما يلي: I- اختبار صحة الفرض الأول، والذي نص على أنه: "يوجد فرق دال إحصائياً بين متوسطي درجات تلاميذ المجموعة التجريبية في التطبيقين القبلي والبعدي للاختبار التحصيلي لصالح التطبيق البعدي". وللتحقق مـن صـحة هذا الفـرض قـام الباحث بالتحليـل الإحصـائي لنتائج تطبيق الاختبـار التحصيلي لتلاميذ العينة التجريبية في التطبيقين القبلي والبعدي.

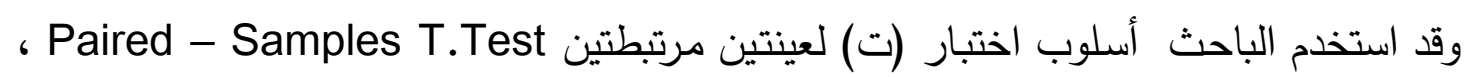
للتعرف على الفرق بين متوسطي درجات تلاميذ المجموعـة التجريبية في التطبيقين القبلي والبعدي للاختبار التحصيلي للمجموعة التجريبية، وكانت النتائج على النحو التالي: جدول (11) نتائج اختبار ت Paired - Samples T. Test للفروق بين متوسطي درجات المجموعة التجريبية فى مستوى التحصيل المعرفي القبلي والبعدي

\begin{tabular}{|c|c|c|c|c|c|c|}
\hline مستوى الدلالة & قيمة "ت" & الحرجية & المعياري & الصسابي & العدد & المجموعة \\
\hline \multirow{2}{*}{$\cdot, \cdots$} & \multirow{2}{*}{ ro, 17} & \multirow{2}{*}{$\leqslant 7$} & $r, \Lambda$ & $\mathrm{V}, \varepsilon$ & \multirow{2}{*}{$\varepsilon V$} & قبلي \\
\hline & & & 0,1 & $r \cdot, r$ & & بعدي \\
\hline
\end{tabular}

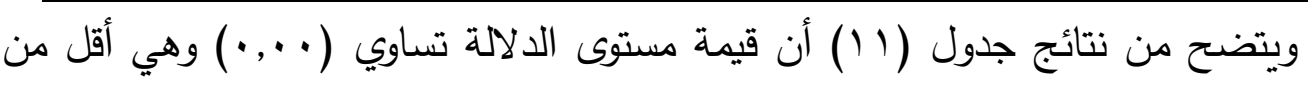

مستوى الدلالة المعنوية (ه.,.) أي أنها دالة إحصائياً، مما يؤكد وجود فروق ذات دلالة إحصائية عند مستوى الدلالة ه., • بين درجات المجموعة التجريبية في مستوى التحصيل المعرفي القبلي والبعدي، لصالح التطبيق البعدي الأعلى في متوسط الدرجات، حيث أن متوسط درجات أفراد المجموعة التجريبية في التطبيق البعدي هو (r, •r)، ومتوسط درجاتهم في التطبيق

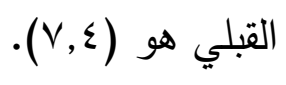

المجلد الثامن- العدد الأول- مسلسل العدد (15)- يناير 2022- الجزء الأول 
وهذا يعني أن مستوى التحصيل البعدي للجوانب المعرفية لتلاميذ المجموعة التجريبية، أكبر من مستوى التحصيل القبلي لهم.

وعلى ذللك يمكن قبول الفرض البحثي الأول للبحث الحالي، وهذا يعني أنها توجد فروق دالة إحصائياً في مستوى تحصيل الجوانب المعرفية، لتلاميذ المجموعة التجريبية في التطبيقين القبلي والبعدي، لصالح التطبيق البعدي. ويوضـح شكل (ع) متوسطي درجات تلاميذ المجموعة التجريبية في التطبيقين القبلي والبعدي للاختبار التحصيلي.

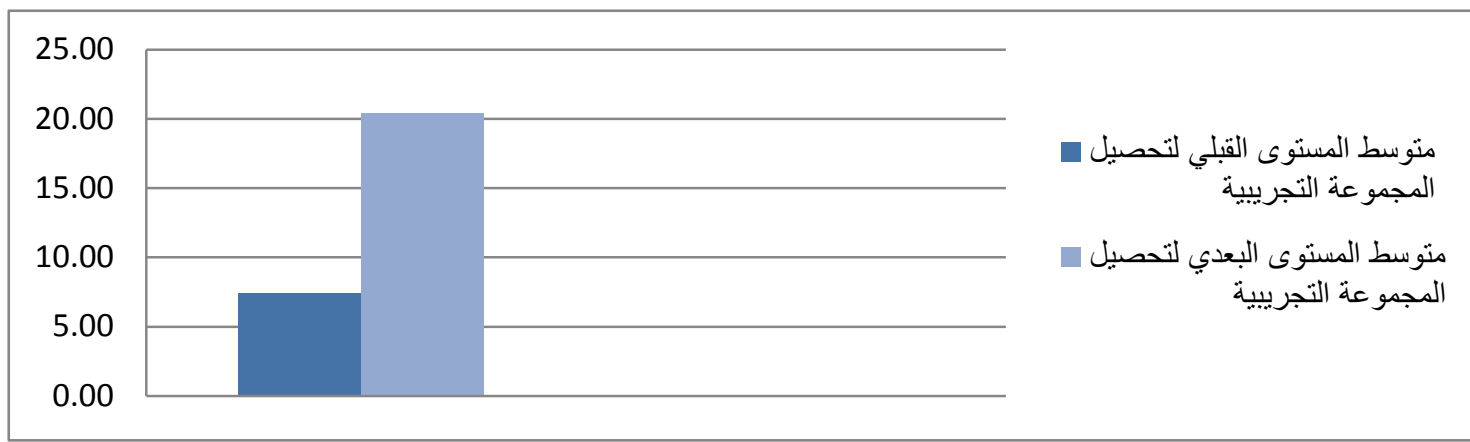

شكل ( ؛ ) متوسطي درجات تلاميذ المجموعة التجريبية في التطبيقين

القبلي والبعدي للاختبار التحصيلي

r- اختبار صحة الفرض الثاني، والذي نص على أنه:

"يوجد فرق دال إحصـائياً بين متوسطي درجات تلاميذ المجموعـة التجريبية، ودرجـات تلاميذ التهيذ المجموعة الضابطة في التطبيق البعدي للاختبار التحصيلي لصالح تلاميذ المجموعة التجريبية." وللتحقق من صحة هذا الفرض قام الباحث بالتحليل الإحصائي لنتائج التطبيق البعدي للاختبار التحصيلي لتلاميذ المجموعتين التجريبية والضابطة.

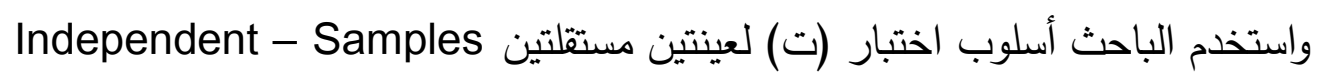
، اللتعرف على الفرق بين متوسطي درجات مستوى التحصيل المعرفي للدى أفراد المجموعتين التجريبية والضابطة، في التطبيق البعدي للاختبار التحصيلي، وكانت النتائج على لى دلى

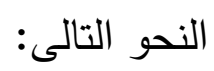

المجلد الثامن- العدد الأول- مسلسل العدد (15)- يناير 2022- الجزء الأول 
جدول (Y l) نتائج اختبار ت Independent - Samples T. Test للفروق

بين متوسطي درجات أفراد المجموعتين التجريبية والضابطة فى مستوى التحصيل المعرفي في التطبيق البعدي للاختبار التحصيلي

\begin{tabular}{|c|c|c|c|c|c|c|}
\hline مستوى الدلالة & قيمة "ت" & درجات & الإنحراف & المستوسط & العدد الع & المجموعة \\
\hline \multirow{2}{*}{$\cdot, \cdots$} & \multirow{2}{*}{$1 \cdot, r_{0}$} & \multirow{2}{*}{91} & $0, r$ & $9, r$ & $\leq 7$ & مجموعة ضابطة \\
\hline & & & 0,1 & $r \cdot, r$ & $\varepsilon V$ & مجموعة تجريبية \\
\hline
\end{tabular}

ويتضح من نتائج جدول (Y Y) أن قيمة قيمة مستوى الدلالة تساوي (· ·, , وهي أقل

من مستوى الدلالة المعنوية (0., •) أي أنها دالة إحصائياً، مما يؤكد وجود فرق دال إحصائياً عند مستوى الدلالـة ه. . • بين أفراد المجموعتين التجريبية والضـابطة، في مستوى التحصيل المعرفي في التطبيق البعدي للاختبار التحصيلي لصالح المجموعة التجريبية، حيث أن متوسط

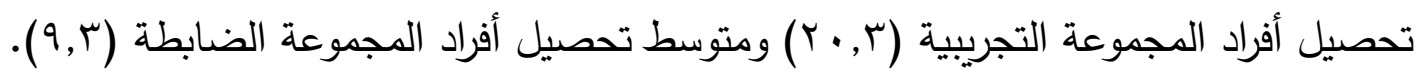
هذا يعني أن مستوى التحصيل البعدي لتلاميذ المجموعة التجريبية، أكبر من مستوى التحصيل البعدي لتلاميذ الهجوعة الضابطة. وعلى ذلك يمكن قبول الفرض البحثي الثاني للبحث الحالي، وهذا يعني أنه توجد فروق

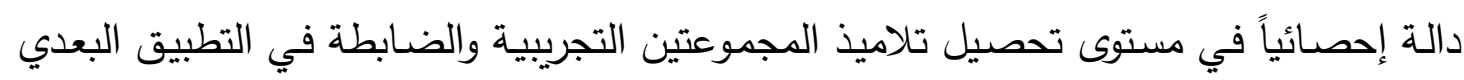
للاختبار التحصيلي لصالح المجموعة التجريبة، ويوضح شكل (0) متوسطي درجات التحصيل المعرفي لتلاميذ المجموعتين التجريبة والضابطة في التطبيق البعدي للاختبار التحصيلي •

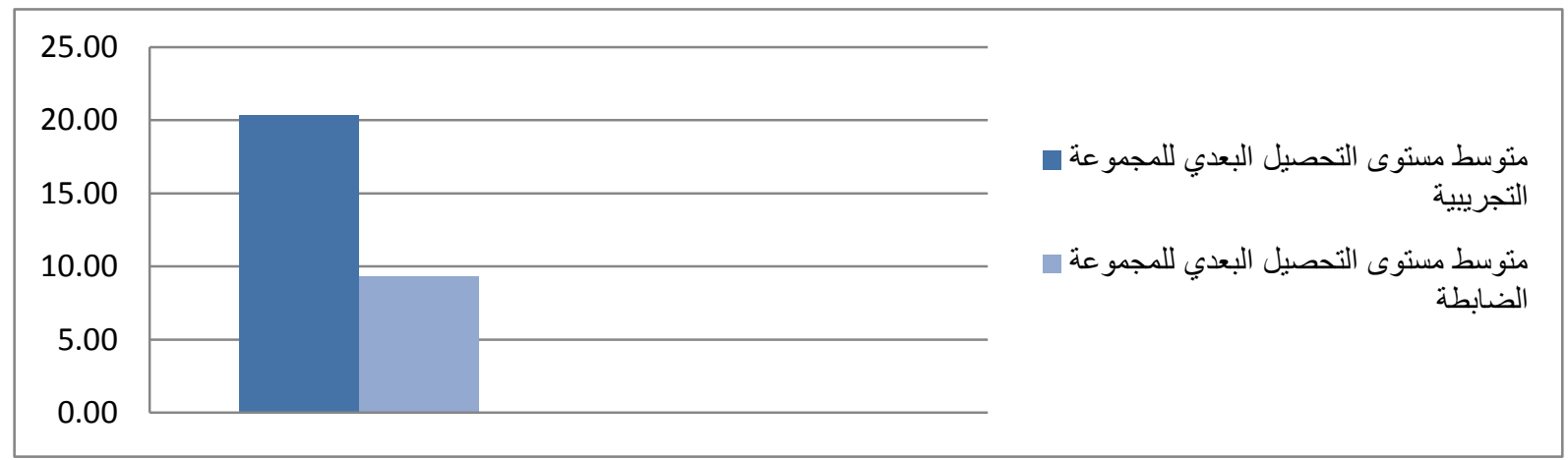

شكل (ه) متوسطي درجات التحصيل المعرفي البعدي لتلاميذ المجموعتين التجريبية والضابطة 
ب- اختبار صحة الفرض الثالث، والذي نص على أنه:

" يوجد أثر للكتاب الإكتروني التفاعلي المقترح في تتمية مستوى التحصيل المعرفي

لاى أفراد العينة التجريبية من تلاميذ الصف الثالث الابتدائي ".

وقد تم حساب حجم الأثر ( Effect Size ) ) للكتاب الإلكتروني التفاعلي

المقترح في تتميـة مسـتوى التحصيل المعرفي لدى تلاميذ المجموعـة التجريبية (أبو حطب،

وصادق،

وكانت النتائج كما هو موضح بالجدول(r ()):

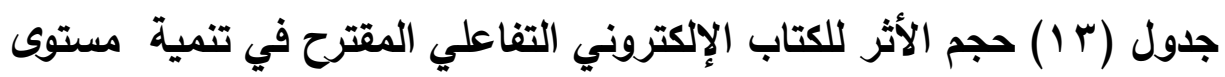

التحصيل المعرفي لاى تلاميذ المجموعة التجريبية

\begin{tabular}{|c|c|c|c|c|c|}
\hline حجم الأثر & مريع إيتا & درجة الحرية & قيمة ت " & قيمة ت & الجانب \\
\hline قوي جداً & . & $\leq 4$ & Trr, & ro,17 & المعرفي \\
\hline
\end{tabular}

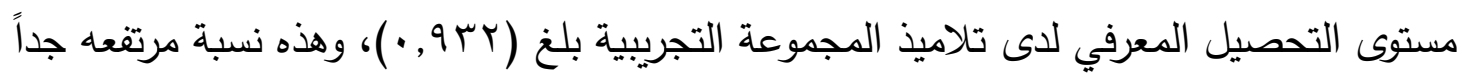

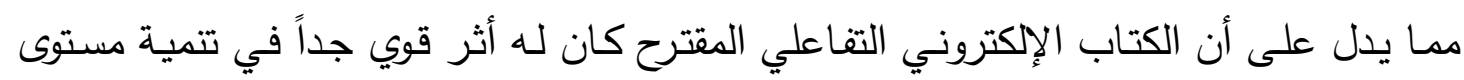
التحصيل المعرفي لدى تلاميذ المجموعة التجريبية، وعلى ذللك يمكن قبول الفرض البحثي الثالث

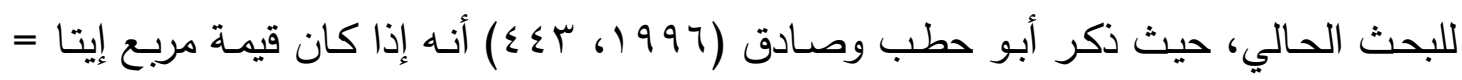

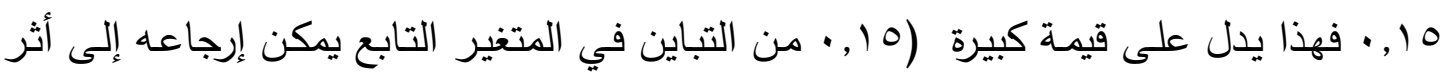

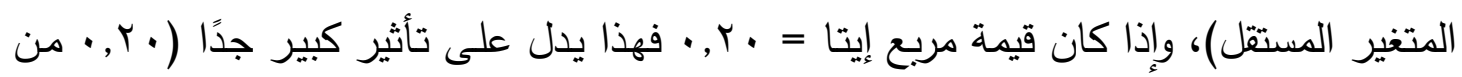
التباين في المتغير التابع يمكن إرجاعه إلى أثر المتغير المستقل). تفسير نتائج البحث ويرجع الباحث هذه النتيجة إلى:

1. التصميم الثيق للكتاب الإلكتروني والذي تم بناؤه في ضوء معايير تصميم الكتاب الإكتروني التفاعلي فقد عرض الكتاب المحتوى التعليمي بشكل متع يجذب حواس الطالب للتفاعل سمعياً وبصرياً معه من خلال الوسائط المتعددة التي يمكنه التحكم فيها، 
والتدرببات التفاعلية التي تقدم له التغذية المرتدة بشكل آمن لتصحيح معلوماته وتحسين خبراته، فضلاً عن طرق التصفح التفاعلية للكتاب التي تشجع الطالب على الاستمرار في عملية التعلم والتنقل بين موضوعاته ومحتوياته بسلاسة ودافعية من خلال الوسائط التكنولوجية الحديثة.

r. معالجة الكتاب الإلكتروني للمحتوي التعليمي للنصوص المقروءة مصحوبة باستراتيجيات القرائية لتحقيق فهم المقروء وهي (التوقع من خلال الصورة والعنوان، التوقع أثناء القراءة، جدول الأسئلة) من خلال التفاعل معه بصرياً والاستجابة المتكررة من قبل الطالب على الأسئلة التفاعلية التي تعمل على زيادة تركيزه وتحمسه لمواصلة التعلم مما يحقق زيادة في التحصيل.

r. عرض الكتاب الإلكتروني المحتوى التعليمي للنصوص المسموعة مع توظيف استراتيجيات القرائية لتحقيق فهم المسموع وهي: (الأسئلة المباشرة والغير مباشرة، التوقع أثناء الاستماع لموضوع الدرس، القصص المسلسلة) من خلال تقسيم الدرس إلى جزئيات متسلسلة ومترابطة مع دفع الطالب للتفاعل معها معتمداً على حاسة السمع والاستجابة المتتابعة على الأسئلة التفاعلية المنطوقة التي تعمل على زيادة تركيزه وتحمسه لمواصلة التعلم وتبث في نفسه الثقة والدافعية نحو التعلم. ع. تتاول الكتاب الإكتروني للمحتوى التعليمي للنصوص بتوظيف استراتيجيات القرائية لتحقيق الطلاقة في القراءة الشفهية وهي (تكرار القراءة الحرة بسرعة ودقة مع الفهر) من خلال التفاعل معه سمعياً وبصرياً والاستجابة المتكررة من قبل التلميذ على الأسئلة التفاعلية التي تعمل على زيادة تركيزه وتحمسه لمواصلة التعلم وتبث في نفسه الثقة؛ وبالتالي نمواً معرفياً متزايداً في التحصيل. ه. تتوع عناصر المحتوى التعليمي للكتاب حيث اشتمل على: النصوص المكتوبة، النصوص المسموعة، الرسوم الثابتة، الرسوم المتحركة (المحببة للأطفال)، الصور الثابتة، الاختبارات التفاعلية، عناصر الإبحار والتفاعل والتحكم في الوسائط. 7. اتبع الكتاب التفاعلي نمط التعزيز الآمن عن طريق اتباع أسلوب التعزيز بالرسوم المتحركة المحببة للطفل، والابتعاد عن التعزيز السلبي الذي يضر بنفسيته. 
V. اعتمد الكتاب طريقة الثرح الذاتي لمحتواه التعليمي حتى يتمكن الطفل من مواصلة التعلم

$$
\text { ومراجعة دروسه بشكل ذاتي داخل وخارج المدرسة. }
$$

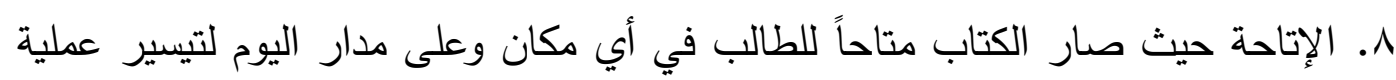

$$
\text { التعلم. }
$$

9. اتجاه الكتاب الإلكتروني لغرس الرغبة في التعلم لاى الطالب، وجعله قادراً على الفهم

والتفكير

\section{وتتفق هذه النتيجة مع دراسة كل من:}

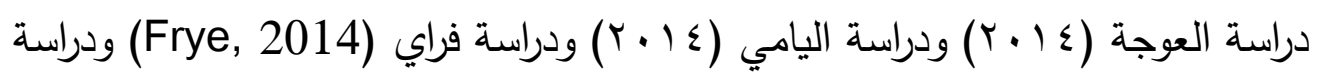

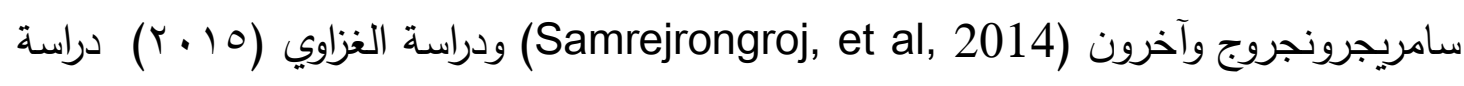

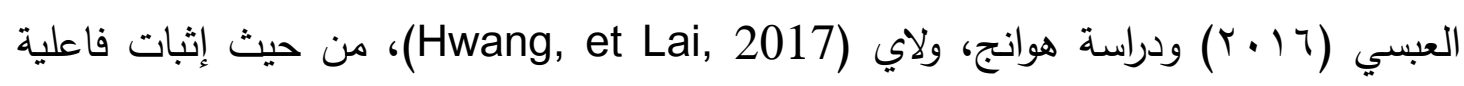
الكتاب الإكتروني التفاعلي، حيث أثثتت جميعها فاعلية الكتاب الإكتروني التفاعلي في تتمية توصيات البحث: التحصيل المعرفي.

ا. الإفادة من الكتاب الإكتروني التفاعلي المقترح في تتمية التحصيل القرائي لتلاميذ

$$
\text { الصف الثالث الابتدائي. }
$$

r. ضرورة الاهتمام بالمحتوى العلمي وطرق تدريسه والاستراتيجيات والأنشطة المتعلقة به وطبيعة المرحلة العمرية للمتعلم من قبل مطوري ومصممي الكتب الإكترونية التفاعلية. r. أهمية التصكك بالطريقة الصوتية تحديداً واستراتيجيات وأنشطة القرائية مع تطويرها رقمياً في تدريس مهارات القراءة لاى تلاميذ مرحلة التعليم الأساسي. ع. تدريب المعلمين على تصميم وإنثاء المحتوى الرقمي والاختبارات الإلكترونية لتوظيفها

$$
\begin{aligned}
& \text { في صقل خبرات ومهارات المتعلمين بسرعة ودقة. } \\
& \text { مقترحات ببحوث مستقبلية: }
\end{aligned}
$$

1. إجراء المزيد من البحوث حول فاعلية الكتاب الإكتروني التفاعلي بتوظيف استراتيجيات وأنشطة القرائية الخاصة بالصوتيات في مراحل التعليم الأولى مثل: (الوعي الصوتي

$$
\text { والمبدأ الأبجدي)، كذلك المفردات، والتراكيب. }
$$

$$
\text { المجلد الثامن- العدد الأول- مسلسل العدد (15)- يناير 2022- الجزء الأول }
$$


ץ. إجراء بحوث خاصة بقياس أثر الكتاب الإلكتروني في تتاول المواد الدراسية في مراحل

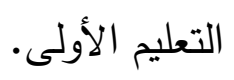

r. إجراء بحوث تقويمية تتناول معوقات الكتاب الإكتروني التفاعلي وسبل تذليلها.

المراجع:

أولاً: المراجع العربية:

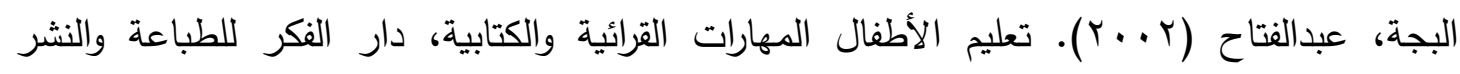
والتوزيع، عمان، الأردن.

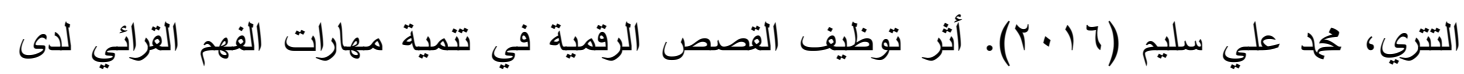
طلاب الصف الثالث الأساسي، رسالة ماجستير منشورة، الجامعة الإسلامية، غزة.

الجنزوري، عباس. (9 . . r). أثر بعض أنماط تصميم الكتاب الإكتروني على تتمية مهارات تشغيل واستخدام مهارات العرض الضوئي لدى طلاب التربية النوعية، رسالة ماجستير غير منشورة،

كلية التربية النوعية، جامعة المنوفية، جمهورية مصر العربية.

الحسن، هشام (........ طرق تعليم الأطفال القراءة والكتابة، طا، عمان، الدار العلمية الدولية،

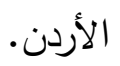

الحسيني، عفاف حسن (ד ؟ (اه). الضعف في القراءة الصامتة تشخيصه وعلاجه، طا، جدة، دار المحاي

الحسيني، هويدا ححمد (ع ( ب). تقويم الكتاب الإلكتروني في اللغة العربية للصف الثالث الابتدائي في ضوء معايير الجودة، دراسات عربية في التربية وعلم النفس، ب(0؛ ).

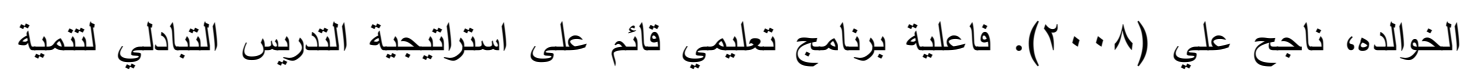
مهارات الفهم القرائي لدى التلاميذ ذوي صعوبات التعلم بالمرحلة الأساسية في الأردن، رسالة دكتوراة، كلية الدراسات التربوية والنفسية العليا، جامعة عمان العربية للدراسات العليا، الأردن.

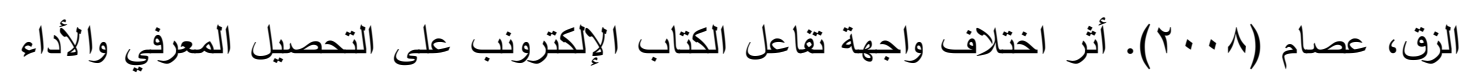
المهاري لدى دارسي ماجستير تقنيات التعلم واتجاهاتهم نحوه، مجلة البحوث النفسية والتربوية

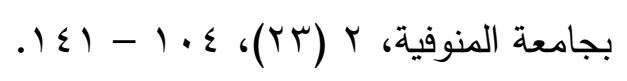

السفاسفة، عبدالرحمن (r ( • r). طرائق تدريس اللغة العربية، مكتبة الفلاح للنشر والتوزيع. 


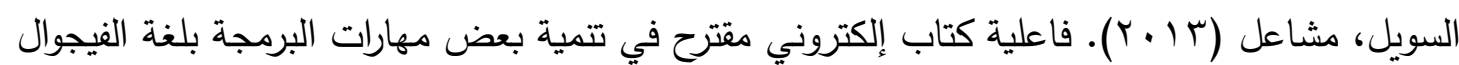
بيسك مقرر الحاسب الآلي لاى طالبات الصف الثاني الثانوي، رسالة ماجستير غير منشورة، برنامج الدراسات العليا التروية، جامعة الملك عبدالعزيز، المملكة العرية السعودية.

السيد، فؤاد البهي (991 ()). علم النفس الإحصائي وقياس العقل البشري، ط به، القاهرة، دار الفكر العربي، ص صبه.

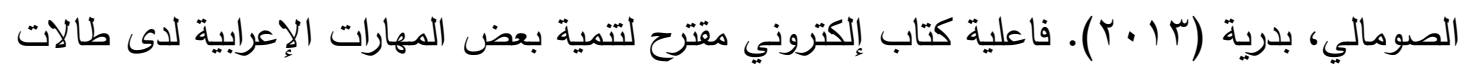
المرحلة الثانوية بمدينة جدة. رسالة ماجستير غير منشورة، برنامج الدراسات العليا التربوية، جامعة الملك عبدالعزيز، المملكة العرية السعودية.

الظاهر، قحطان (1 . . ץ). صعوبات التعلم، الطبعة الثانية، دار وائل للنشر والتوزيع الأردن، عمان. العبسي، زكريا فؤاد زكي (T ( • Y). أثر توظيف كتاب تفاعلي في تتمية المفاهيم ومهارات التفكير فوق المعرفي بمادة العلوم لاى طالبات الصف السابع الأساسي، رسالة ماجستير، كلية التربية، الجامعة الإسلامية، غزة.

العرينان، هديل (10 • r). فاعلية استخدام القصص الإكترونية في تتمية بعض المهارات اللغوية لدى طفل الروضة، رسالة ماجستير ، جامعة أم القرى، المملكة العربية السعودية. العمرو، عرين سلامة (0 1 ب). أثر برمجية تعليمية في إكساب مهارات القراءة لأطفال رياض الأطفال، رسالة ماجستير، جامعة مؤتة، الأردن. العمري، منصور (Y ( †). فاعلية استخدام كتاب إلكتروني في مادة المطالعة على التحصيل الدراسي لاى طلاب الصف الأول الثانوي، مجلة القراءة والمعرفة، ا ( سبا ).

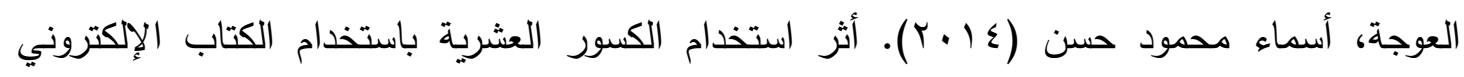
التفاعلي وتطبيق إدارة الغرفة الصفية في اكتساب مهارات الحس العددي وتتمية مهارات التواصل الرياضي لدى طلبة الصف الخامس الأساسي في الأردن، رسالة ماجستير، كلية الدراسات العليا، الجامعة الأردنية، الأردن. الغزاوي، إيمان أحمد فهمي (10 • r). أثر أنماط التفاعل مع النص والصورة داخل الكتاب الإكتروني في التحصيل الفوري والمرجأ لتلاميذ المرحلة الابتدائية وتتمية اتجاهاتهم نحو الكتب الإكترونية، رسالة دكتوراة، كلية التربية النوعية، جامعة بور سعيد، مصر • الغلبان، حاتم خالد صالح (ع ( †). أثر توظيف استراتيجيتين للتعلم النشط في تتمية مهارات الفهم القرائي لدى تلميذات الصف الرابع الأساسي، رسالة ماجستير، كلية التربية، الجامعة الإسلامية، 
الكميشي، لطفية (اسـ (هـ). الكتاب الإلكتروني، مجلة المعلوماتية، العدد الثاني والثلاثون. روجعَ بتاريخ T

http://www.informatics.gov.sa/articles.php?artid=209

الححلي، مروة مححد جمال الدين (Y ( • Y). أثر استخدام كتاب إلكتروني تفاعلي مقترح لمقرر تحليل النظم والتصميم في تتمية الجوانب المعرفية والمهارية لطلاب الدبلوم العامة شعبة الكمبيوتر التعليمي، رسالة ماجستير ، كلية الدراسات التربوية، جامعة القاهرة، مصر • الميعان، هند أحمد (T ( + Y). أثر استخدام استراتيجية التدريس التبادلي على الفهم القرائي والاتجاه نحو القراءة لاى طالبات الصف السابع بدولة الكويت، مجلة الدراسات التربوية والنفسية، جامعة

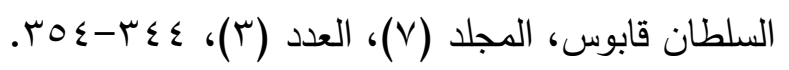

الهلالي، عبيد الله بن رده (10 • ب). فاعلية برنامج أتقن في تتمية مهارات القراءة لدى تلاميذ الصف الثاني الابتدائي، رسالة ماجستير، كلية التربية، جامعة أم القرى، المملكة العربية السعودية. اليامي، هدى بنت يحيى (ع ( • (Interactive eBook) فاعلية كتاب إلكتروني تفاعلي لتمية مهارات تصميم وتوظيف الرحلات المعرفية عبر الويب (Web Quests) لدى الطالبات المعلمات، رسالة دكتوراة، كلية التربية، جامعة أم القرى، المملكة العربية السعودية. أبو الدهب، محمود محمد أحمد، ويونس، سيد شعبان عبدالعليم (T/ ب). فاعلية اختلاف بعض أنماط تصميم الكتاب الإكتروني التفاعلي في تتمية مهارات تصميم وإنتاج المقررات الإلكترونية لدى

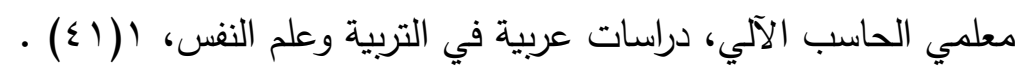

أبو الريش، مريم أحمد حسين (10 • ( ). أثر استخدام استراتيجيتي (SNIPS) و (SQ3R) في الفهم القرائي والتحصيل واكتساب المفردات لدى طلبة المرحلة الأساسية في فلسطين، رسالة دكتوراة، كلية الدراسات العليا، الجامعة الأردنية، الأردن. أبو الهيجاء، فؤاد حسن حسين (r . . r). أساليب وطرق تدريس اللغة العربية، الطبعة الثانية، دار المناهج، عمان. أبو الهيجاء، فؤاد حسن (V . . Y). أساليب وطرق تدريس اللغة العربية، طس، عمان، دار المناهج للنشر والتوزيع.

أبو حطب، فؤاد، وصادق، أمال (997 (1). مناهج البحث وطرق التحليل الإحصائي في العلوم النفسية والتربوية والاجتماعية، طץ، القاهرة، مكتبة الأنجلو المصرية، ص وسع. 
أبو زايدة، أحمد علي (r (ب). فاعلية كتاب تفاعلي محوسب في تتمية مهارات التفكير البصري في التكنولوجيا لدى طلاب الصف الخامس الأساسي بغزة، رسالة ماجستير، كلية التربية، الجامعة

$$
\text { الإسلامية، غزة. }
$$

جابر ، وليد (1991) . أساليب تدريس اللغة العربية، الطبعة الثالثة، الأردن، عمان، دار الفكر . حجازي، أميرة (11 (ب). أثر التفاعل بين بنية الإبحار داخل الكتاب الإككتروني والأساليب المعرفية في تنمية مهارات حل المشكلات .رسالة ماجستير غير منشورة، كلية التربية النوعية، جامعة عين

$$
\text { شمس، جهورية مصر العربية. }
$$

خلف، عواطف عبدالله حسن (V. . . . . أثر استخدام أسلوب التدريس التبادلي على مستوى الفهم القرائي ودافعية القراءة لدى التلميذات ذوات صعوبات التعلم بالمرحلة الابتدائية بدولة الكويت، رسالة

$$
\text { ماجستير، كلية الدراسات العليا، جامعة الخليج العربي، مملكة البحرين. }
$$

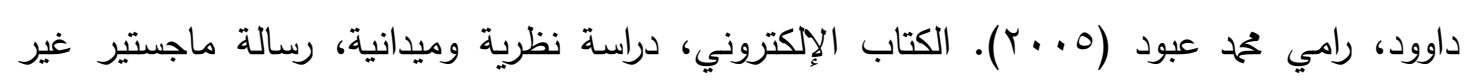

$$
\text { منشورة، كلية الآداب، جامعة المنوفية. }
$$

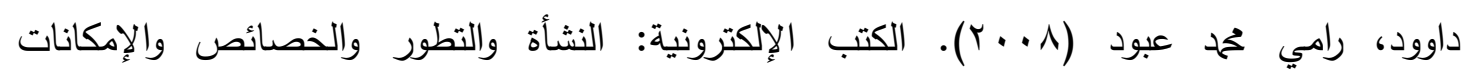
والاستخدامات والإفادة، الدار المصرية اللبنانية، القاهرة.

سيد، أحمد ( • ( ب). الكتاب الإكتروني إنتاجه ونشره، الرياض، مكتبة الملك فهد الوطنية. سمك، محمد صالح (9191 (1). فن التدريس للغة العربية والتربية الدينية، طب دار الفكر العربي: القاهرة.

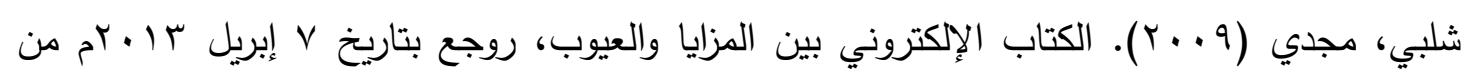
الرابط:

خلال

http://pulpit.alwatanvoice.com/articles/2009/03/23/160209.html عبدالكريم، خليفة (1) ( ب). فعالية التعلم الفردي الاتي بالمحاكاة بالحاسوب والكتاب الإلكتروني في تتمية التفكير الابتكاري، مجلة كلية التربية بأسيوط ، Y (YV).

عزت، حمح فريد (r (r). نشأة الكتاب الإكتروني وتطوره، ومميزاته، وسلبياته، مجلة التربية، قطر

$$
\text { r) }
$$

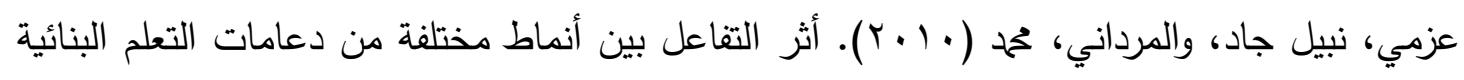
داخل الكتاب الإكتروني في التحصيل وكفاءة التعلم لدى طلاب الدراسات العليا بكليات

$$
\text { التربية. دراسات تربوية واجتماعية، ب (7 ( ) ) }
$$

عون، فاضل ناهي (Y (Y). طرائق تدريس اللغة العربية وأساليب تدريسها، طا، عمان، دار صفاء للنشر والتوزيع. 
فرجون، خالد مححد محمد (ب991). أثر التفاعل بين الأسلوب المعرفي ونمط الشكل التوضيحي لخطوات تشغيل دائرة تلفزيونية مغلقة على السرعة والدقة في الأداء، رسالة ماجستير غير منشورة، كلية

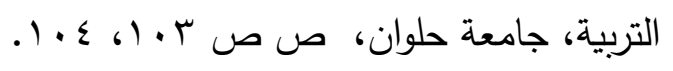

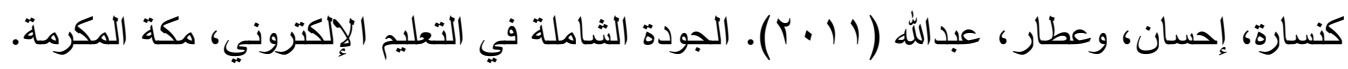
مبارز، منال (^ . ؟ץ). فاعلية كتاب إلكتروني في تتمية مهارات إنتاج عروض الوسائط المتعددة لمعلمات الروضة، بحث مقدم في مؤتمر تكنولوجيا التربية وتعليم الطفل العربي، جامعة القاهرة، جمهورية مصر العربية.

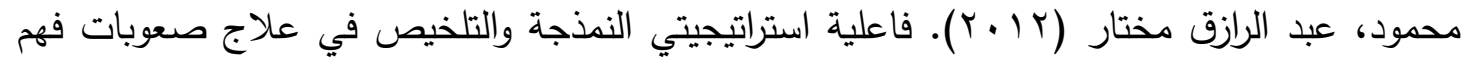
المقروء وخفض قلق القراءة لدى دارسات المدارس الصديقة للفتيات، المجلة الدولية للأبحاث

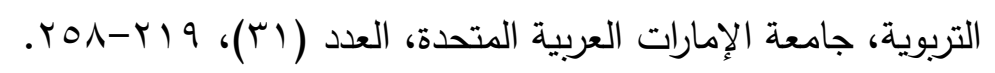

مدكور، علي أحمد ( . . . ( ). تدريس فنون اللغة العربية، الكويت، مكتبة الفلاح.

مصطفى، رياض بدري (Y0 (10). مشكلات القراءة من الطفولة إلى المراهقة (التشخيص والعلاج)،

$$
\text { الطبعة الأولى، الأردن، عمان، دار صفاء. }
$$

نصار ، دينا (1) (1). فاعلية الكتاب الإكتروني على تتمية كل من مهارة صيانة الحاسب الآلي والذكاء البصري/ المكاني لدى طلاب الفرقة الرابعة شعبة معلم حاسب آلي، رسالة ماجستير غير

منشورة، كلية التربية النوعية، جامعة طنطا، جمهورية مصر العربية.

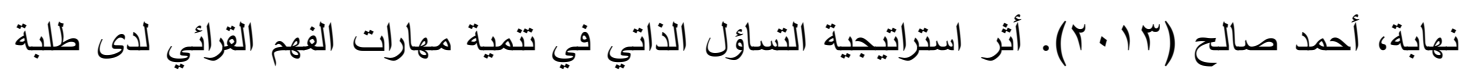

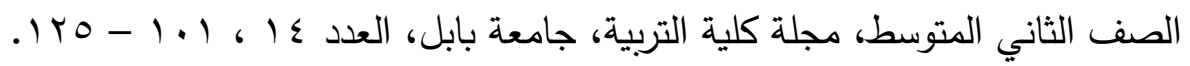
الدليل الإرشادي مشروع تحسين الأداء التعليمي للبنات GILO GO (11). برنامج تتمية مهارات القراءة في الصفوف الدراسية الأولى، دليل المدرب، وزارة التربية والتعليم، جمهورية مصر العربية.

ثانياً: المراجع الأجنبية

Abdelrazek, M, \& ElModyan, A (2013). Towards an Adaptive e Book, the Third International Conference of e-Learning and Distance Education (eLi3), Riyadh: National Center for eLearning \& Distance Learning.

Aly, A, \& Gabal, R. (2010). Effect of using e book and programmed paper Book on Some Learning Aspects of physical Education Lesson (Comparative Study). World Journal of Sport Sciences, 3 ( 4 ), $261-268$. 
Chen, J.; Chen, M. and Sun, Y. (2010). A novel approach for enhancing student reading comprehension and assisting teacher assessment of literacy.

Ciampa, Katia. (2012). Reading in the Digital Age: Using Electronic Books as a Teaching Tool for Beginning Readers. Canadian Journal of Learning and Technology, 38(2), 72-98.

Estrada, P., \& Conaway, R. (2012). EBooks: The Next Step in Educational. Business Communication Quarterly, 75(2), 125-135.

Binas, P., Stancel, M., \& Michalko, M. (2012). Interactive eBook as a Supporting Tool for Education Process. Institute of Electrical and Electronics Engineers (IEEE) 10th International Conference. Slovakia. 39-44.

Beer, W, \& Wagner. A. (2011). Smart books: adding context-awareness and interaction to electronic books. 9th International Conference on Advances in Mobile Computing and Multimedia. USA: Association for Computing Machinery (ACM). 218-222.

Frye, S. (2014). The implications of interactive ebooks on comprehension. Unpublished Doctoral Thesis, Graduate School of Education, Rutgers University, New Jersey. USA.

Hwang, G. J., \& Lai, C. L. (2017). Facilitating and Bridging Out-OfClass and In-Class Learning: An Interactive E-Book-Based Flipped Learning Approach for Math Courses. Journal of Educational Technology \& Society, 20(1), 184-197.

Johnson, K. (2014). The Cumulative Effect of Hyperactivity and Peer Relationships on Reading Comprehension. Journal of Education and Training Studies, V. (2), N. (1), 98 - 102.

Kissinger, J.(2013). The Social \& Mobile Learning Experiences of Students Using Mobile ebooks. Journal of Asynchronous Learning Networks, 17(1), 155-170.

Pagan, S., \& Senechal, M. (2014). Involving Parents in a Summer Book Reading Program to Promote Reading Comprehension, Fluency, and Vocabulary in Grade 3 and Grade 5 Children. Canadian Journal of Education, V. (37), N. (2) , 1-31.

Samrejrongroj, P., Boonsiri, T., Thunyaharn, S., \& Sangarun, P. (2014). The Effectiveness Of Implementing An E-Book: Antigen And Antibody Reaction For Diagnosis Of Diseases In Microbiology

$$
\text { المجلد الثامن- العدد الأول- مسلسل العدد (15)- يناير 2022- الجزء الأول }
$$


Learning. Journal of College Teaching \& Learning (TLC), 11(1), $35-44$.

Farag, Mona. (2011). The use of the electronic book (eBook) in Developing English Reading Skills among Second Year Preparatory school Students. Unpublished Master Thesis, Department of Curriculum \& Instruction, Minoufiya University, Cairo. 